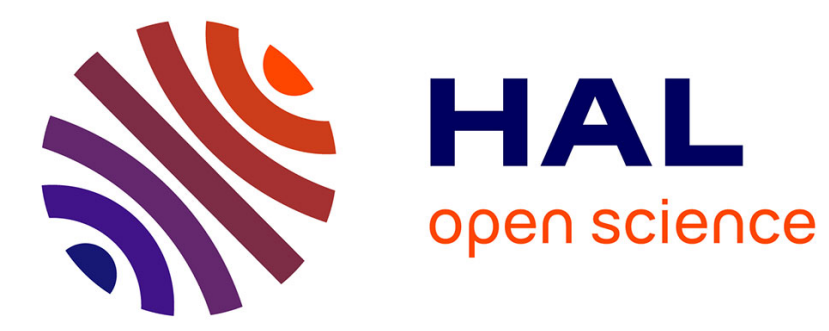

\title{
Interactions between smectites and polyelectrolytes
}

Cheng Cheng Shen, Sabine Petit, Cun Jun Li, Chun Sheng Li, Nafeesa

Khatoon, Chun Hui Zhou

\section{To cite this version:}

Cheng Cheng Shen, Sabine Petit, Cun Jun Li, Chun Sheng Li, Nafeesa Khatoon, et al.. Interactions between smectites and polyelectrolytes. Applied Clay Science, 2020, 198, pp.105778. 10.1016/j.clay.2020.105778 . hal-03000670

\section{HAL Id: hal-03000670 \\ https://hal.science/hal-03000670}

Submitted on 2 Dec 2020

HAL is a multi-disciplinary open access archive for the deposit and dissemination of scientific research documents, whether they are published or not. The documents may come from teaching and research institutions in France or abroad, or from public or private research centers.
L'archive ouverte pluridisciplinaire HAL, est destinée au dépôt et à la diffusion de documents scientifiques de niveau recherche, publiés ou non, émanant des établissements d'enseignement et de recherche français ou étrangers, des laboratoires publics ou privés. 


\title{
Interactions between Smectites and Polyelectrolytes
}

Cheng Cheng Shen ${ }^{\mathrm{a}, \mathrm{c}}$, Sabine Petit ${ }^{\mathrm{d}}$, Cun Jun $\mathrm{Li}^{\mathrm{a}}$, Chun Sheng $\mathrm{Li}^{\mathrm{b}}$, Nafeesa Khatoona, Chun Hui $\mathrm{Zhou}^{\mathrm{a}, \mathrm{b}, \mathrm{c}, \square}$

${ }^{a}$ Research Group for Advanced Materials \& Sustainable Catalysis (AMSC), State Key Laboratory Breeding Base of Green Chemistry-Synthesis Technology, College of Chemical Engineering, Zhejiang University of Technology, Hangzhou 310032, China

${ }^{\mathrm{b}}$ Key Laboratory of Clay Minerals of Ministry of Land and Resources of the People's Republic of China, Engineering Research Center of Non-metallic Minerals of Zhejiang Province, Zhejiang Institute of Geology and Mineral Resource, Hangzhou 310007, China

${ }^{c}$ Qing Yang Institute for Industrial Minerals, You Hua, Qing Yang, Chi Zhou 242804, China

${ }^{\mathrm{d}}$ Institut de Chimie des Milieux et Matériaux de Poitiers (IC2MP), UMR 7285 CNRS, Université de Poitiers, Poitiers Cedex 9, France

Corresponding author: Prof. Chun Hui ZHOU. E-mail: clay@zjut.edu.cn

\begin{abstract}
Interactions between smectite and polyelectrolyte play an essential role in exclusive adsorption, flocculation, and thixotropic properties of aqueous smectite/polyelectrolyte system. The materials are widely used in many industries such as drilling fluids, pharmaceuticals, paints and dyes, ceramics, papermaking and water treatment. This review focuses on the interaction between different types of polyelectrolytes and smectite, and their applications in flocculation and industrial wastewaters. The effect of several parameters related to polyelectrolyte such as charge density, charge type and molecular weight, as well as to smectite such as type, particle size, composition, $\mathrm{pH}$ and concentration in the aqueous system, were examined. The interactive forces between smectite and polyelectrolyte including hydrophobic interaction, ion binding, hydrogen bonding, van der Waals forces and electrostatic were thoroughly discussed. The interactive forces between smectite and cationic polyelectrolyte, anionic polyelectrolyte and amphoteric polyelectrolyte influence the flocculation of colloidal smectite-polyelectrolyte dispersions such as settling and floc dispersion. However, the interaction between smectites and polyelectrolytes and their subsequent behaviors in adsorption, flocculation, and thixotropy along with inherent mechanisms have not yet fully understood. Future in-depth work on interactions between smectites and polyelectrolytes has great implications for developing functional materials and expanding applications of other polyelectrolyte/ smectite mineral system.
\end{abstract}

Keywords: Smectites; Polyelectrolytes; Interaction; Adsorption; Flocculation; Rheology. 


\section{Introduction}

Smectite refers to a family of layered aluminosilicate that possesses peculiar cation exchange capacity (CEC), surface reactivity and adsorption. Typically, smectite's layered structure is composed of -Si-O-Mg (Al or Li)-O-Si- layers separated by hydrated cations (e.g. $\mathrm{Na}^{+}, \mathrm{NH}^{4+}, \mathrm{Li}^{+}$, $\mathrm{K}^{+}$and $\left.\mathrm{Mg}^{2+}\right)$ in the interlayer space where each layer consists of two Si-O-Si tetrahedral sheets sandwiching an octahedral sheet (Fig. 1a). According to how much the center space of the octahedron is occupied with metal cation, clay minerals in smectite family are divided into dioctahedral ones such as montmorillonite, and trioctahedral one such as saponite and hectorite (Bergaya and Lagaly, 2013; Ismadji et al., 2015). A commercially available synthetic hectorite is known as laponite ${ }^{\circledR}$. Montmorillonite, saponite and hectorite have physical and chemical properties in swelling and delamination. The layers have amphoteric properties and carry a permanent negative charge and localized positive charges (or negative charges at high $\mathrm{pH}, \mathrm{pH}>9$ ) (Sposito et al., 1999; Dawson and Oreffo, 2013) (Fig. 1b). The layers and relevant smectite particles readily give rise to interactions between the smectite particle surfaces and polyelectrolytes including hydrogen bonding, hydrophobic interactions, ion binding, van der Waals forces, electrostatic attraction, and electrostatic repulsion (Song et al., 2010).

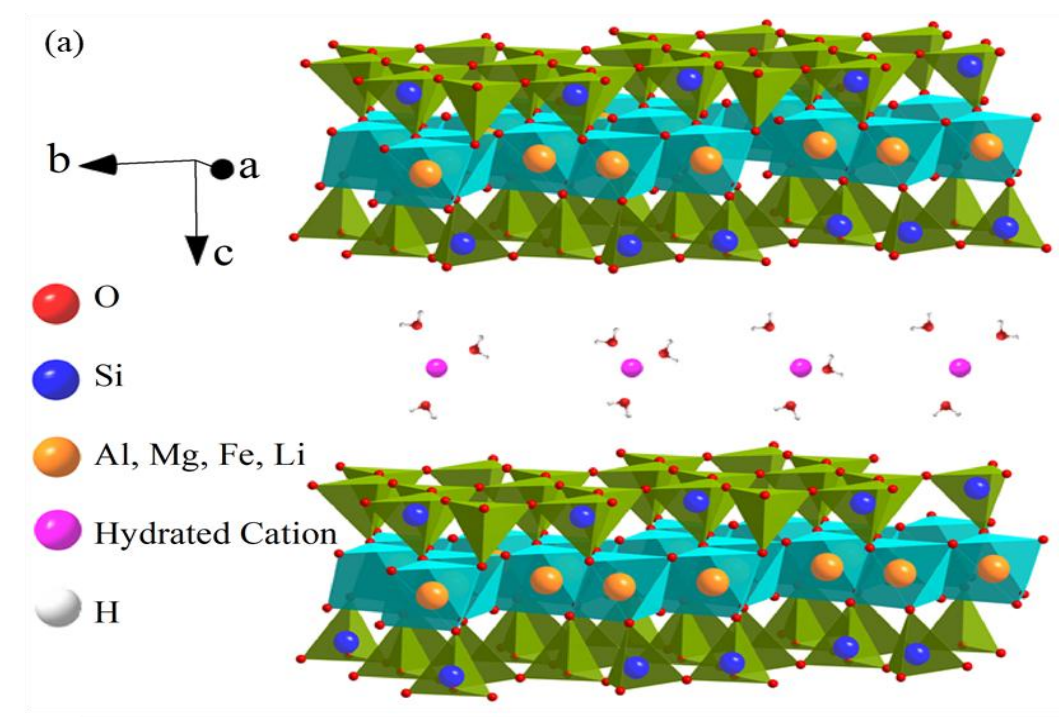

(b)

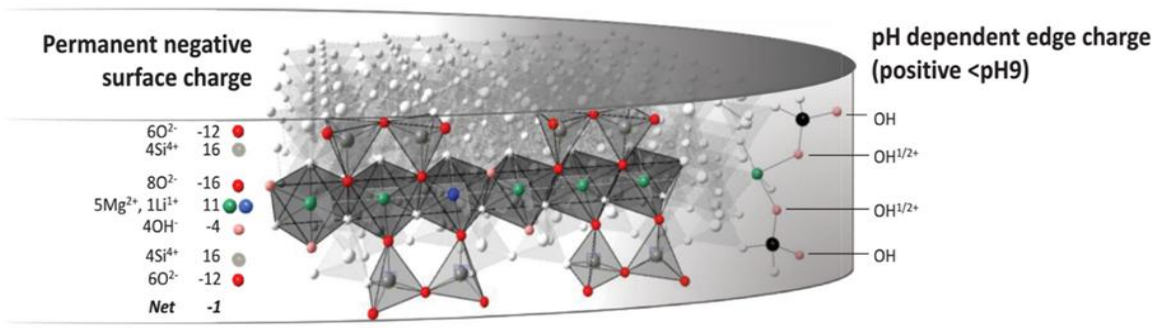

Fig.1. Smectite and its surface properties (a) The structure of smectite: layer is composed of two tetrahedral silica sheets sandwiching an octahedral sheet (with $\mathrm{Al}^{3+}, \mathrm{Li}^{+}, \mathrm{Mg}^{2+}$, and $\mathrm{Fe}^{2+}$ or $\mathrm{Fe}^{3+}$ as octahedral cations). Charge deficiencies in the octahedral and/or tetrahedral sheets yield a negative surface charge balanced by exchangeable cations in the interlayer space. (b) Smectites possess a permanent negative surface charge arising from isomorphic substitutions in the crystal structure and a $\mathrm{pH}$ dependent edge charge from unsatisfied valences in the disrupted 
crystal lattice. Reprinted from. (Reprinted by permission from John Wiley and Sons: (Dawson and Oreffo, 2013), copyright 2013).

Smectites and polyelectrolytes are widely used in pharmaceuticals, drilling fluids, water treatment, ceramics, papermaking, paints and dyes (Carli et al., 2015; Xiao et al., 2016). Polyelectrolytes are a class of specific polymers of which repeating units bear electrolyte groups. They can be categorized into cationic, anionic and amphoteric polyelectrolytes. These polyelectrolytes can coexist with smectite in water and can vary their properties such as the adsorption, flocculation rheology and thixotropy primarily due to interaction between aqueous smectite and polyelectrolytes (Kim and Carty, 2016; Shaikh et al., 2017a). Hence, the interaction between smectite and polyelectrolyte has captured many researchers' interest and attention. The relevant applications and implications have been significantly widened (Fig. 2b).

The interactions between smectite and polyelectrolyte depend on the physical and chemical properties of smectites, polyelectrolytes, and medium. The polymeric structure of the polyelectrolyte, the chemical structure of monomer in the backbone, the charge distribution in monomeric groups and their distribution along the polyelectrolyte chains, are influential (Shaikh et al., 2017b). The polyelectrolyte concentration in water, molecular weight and functional groups are also critically important for the interactions between smectite and polyelectrolyte. In addition, the smectite-polyelectrolyte interactions in aqueous medium also depend on the size, shape, surface charge, and concentration of the smectite particles. Besides the $\mathrm{pH}$ and the temperature, the medium also has an impact on the smectite-polyelectrolyte interactions in water (Alemdar et al., 2005; Oliyaei et al., 2015).

Addition of polyelectrolytes into aqueous smectite dispersion remarkably modifies the surface properties of the smectite and consequently changes the smectite particle-particle interactions. This might lead to exclusive adsorptive (Abdullah et al., 2013), flocculent (Mansri et al., 2019), rheological and thixotropic properties (Abu-Jdayil, 2011; Aalaie, 2012; Aydin et al., 2015). These interactions between smectites and polyelectrolytes can be utilized in pharmaceuticals (Viseras et al., 2010), oil and gas drilling fluids (Falode et al., 2008; Karagüzel et al., 2010; Vipulanandan and Mohammed, 2014), paints and dyes (Wang et al., 2014), paper-making industry (Zhang et al., 2013b), environmental remediation (Ismadji et al., 2015) and water treatment of smectites (Lee et al., 2014; Santhosh et al., 2016). For example, smectites as adsorbents and polyelectrolytes as flocculants are used for separation to treat industrial wastewaters (Marchuk et al., 2016) due to their cost- effectiveness (Sievers et al., 2015), versatility (Silva et al., 2016), high efficiency (Vereb et al., 2017) and relatively low toxicity (Van Haver and Nayar, 2017). In drilling fluid, smectite nanoparticles, along with polyelectrolytes, has been widely used to improve the rheology and filtration properties (Yu et al., 2018; Zhou et al., 2016).

It is evident that interactions between smectites and polyelectrolytes are of great scientific and technological significance (Fig. 2a). The study of such interactions has become greatly 
multidisciplinary involving colloid and interface science, rheology, materials science, mineralogy and chemistry. Current research primarily focuses on the interaction between smectites and polyelectrolytes. Studies clearly reveal that the adsorption of polyelectrolytes to smectites affects their structure and chemical properties, flocculation and rheological behavior. Traditionally, the interaction between smectites and polyelectrolytes is used for developing adsorbent, flocculants, rheological additives and catalysts (Fig. 2b). Recently, this interaction is increasingly used for making hierarchical materials, tissue engineering materials, biosensors and drug carriers. For example, halloysite-polyelectrolytes interactions and illite-polyelectrolytes interactions has been intensively used for making biomedical composites (Zhao et al., 2015; Zhen et al., 2016; Tarasova et al., 2019).

110

(a)

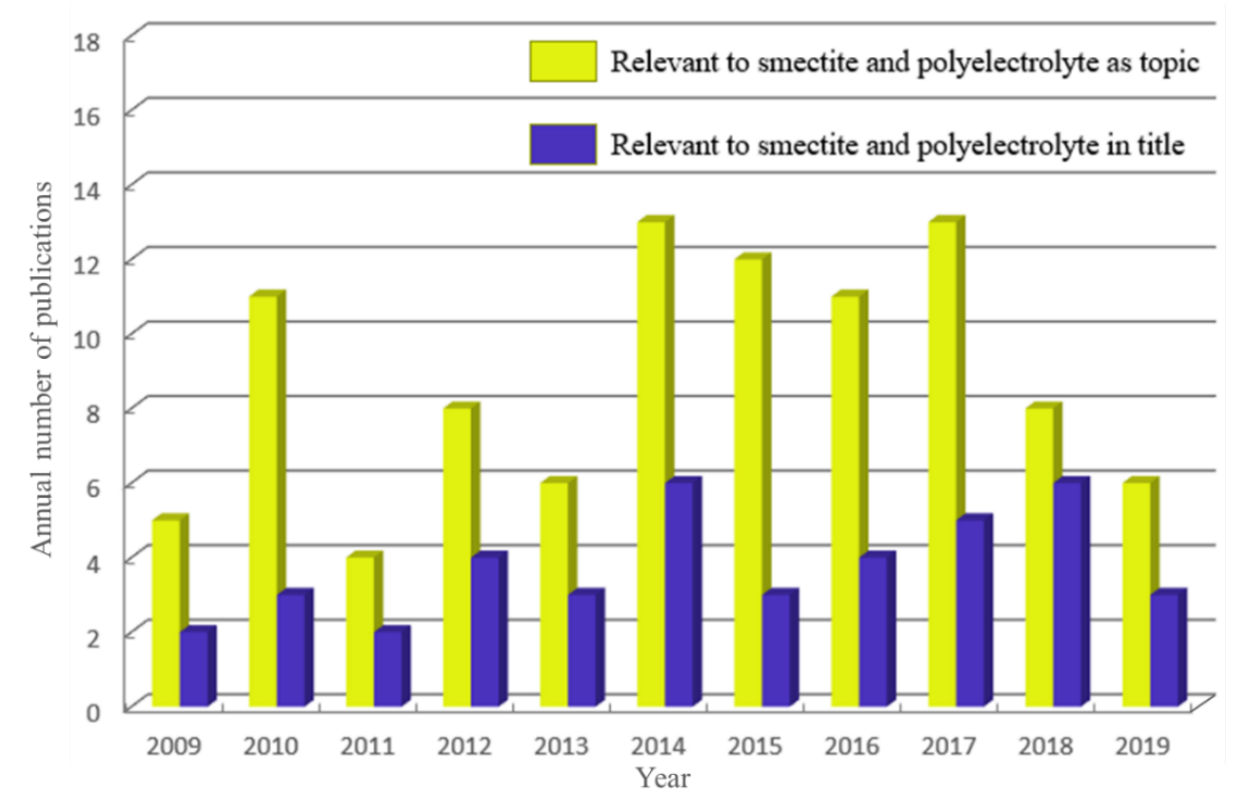

(b)

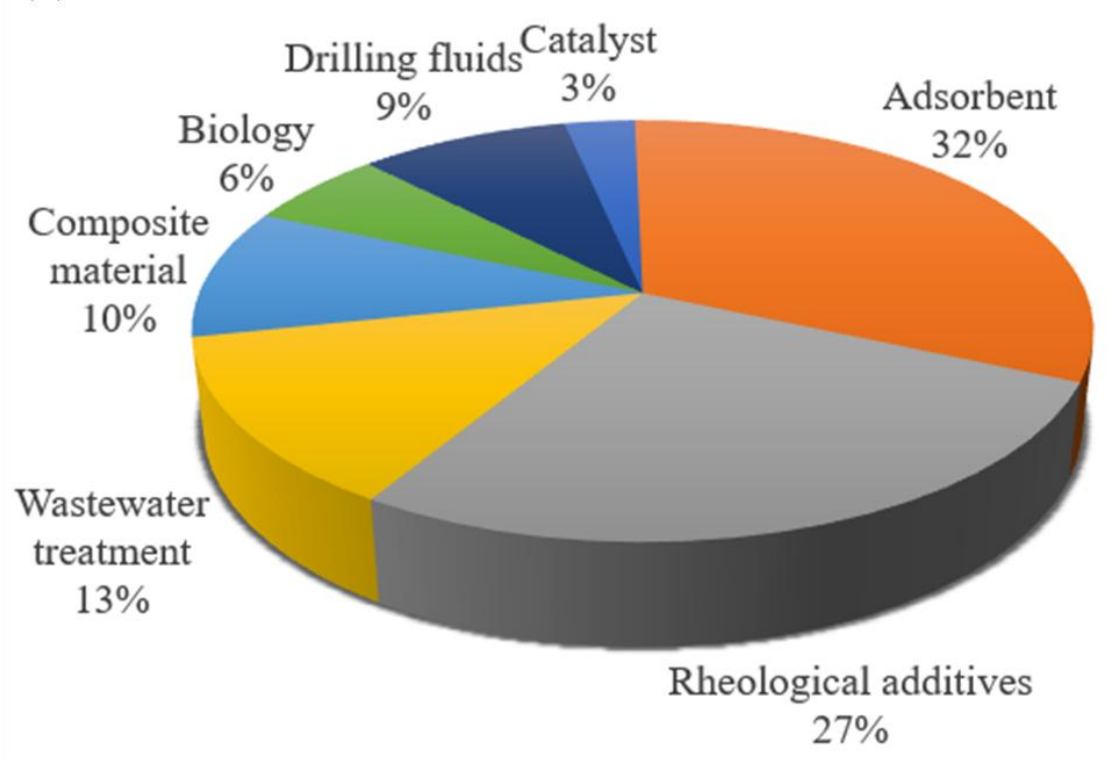


Fig. 2. (a) Annual number of peer-reviewed papers (published from 2009 to 2019) relevant to the topic of interactions between polyelectrolytes and smectites. Data from Web of Science Core Collection and by searching for terms in topic: smectites, polyelectrolytes and interactions; (b) Data from Web of Science Core Collection and by searching for terms in topic: montmorillonite, polyelectrolytes and application, saponite, polyelectrolytes and application, hectorite or laponite, polyelectrolytes and application, and Results Analysis according to peer-reviewed scientific papers indexed in Web of Science Core Collection (published from 2009 to 2019).

In the present paper, the interactions between smectites (montmorillonite, saponite, and hectorite) and polyelectrolytes (cationic, anionic, and amphoteric) are overviewed. The insights into the effects of the interactions on adsorption, flocculation, and rheology and related applications are critically examined. Then, the existing problems and challenges are analyzed and discussed.

\section{Cationic polyelectrolytes}

\subsection{Montmorillonite}

Montmorillonite layer possesses negative charges while the layer edges have variable charges at different $\mathrm{pH}$ whereas cationic polyelectrolytes bear positively charged functional groups. Kraft lignin-acrylamide (KAD), polyacrylamide (PAM), tertiary amine methacrylate (TAM), poly(acrylamide-co-(N-octyl-4-vinylpyridinium bromide)) and chitosan are typical cationic polyelectrolytes which can readily interact with smectite (Fig. 3). The interactions subsequently influence the adsorption, flocculation and rheological behavior of montmorillonite in water (Table 1). Generally, cationic polyelectrolytes induce flocculation via charge neutralization, patching, polymer bridging, or combination of these interactions (Petzold and Schwarz, 2013, Zhou et al., 2019a). Charged polyelectrolytes adsorbed on the surface of micro or nano form of montmorillonite mainly through electrostatic interactions (Shaikh et al., 2017a). The amount of adsorption mainly depends on the surface charge density of montmorillonite and the type of charge of polyelectrolyte (Sakhawoth et al., 2017). Montmorillonite-polyelectrolyte system is mostly used in agriculture (Ismadji et al., 2015), construction, drilling fluid (de Figueiredo et al., 2014), and paints (de Figueiredo et al., 2014). It is also known to use in other fields such as pharmaceuticals (Viseras et al., 2010), environmental remediation (Ismadji et al., 2015) and water treatment (Beisebekov et al., 2014, Lee et al., 2014). 

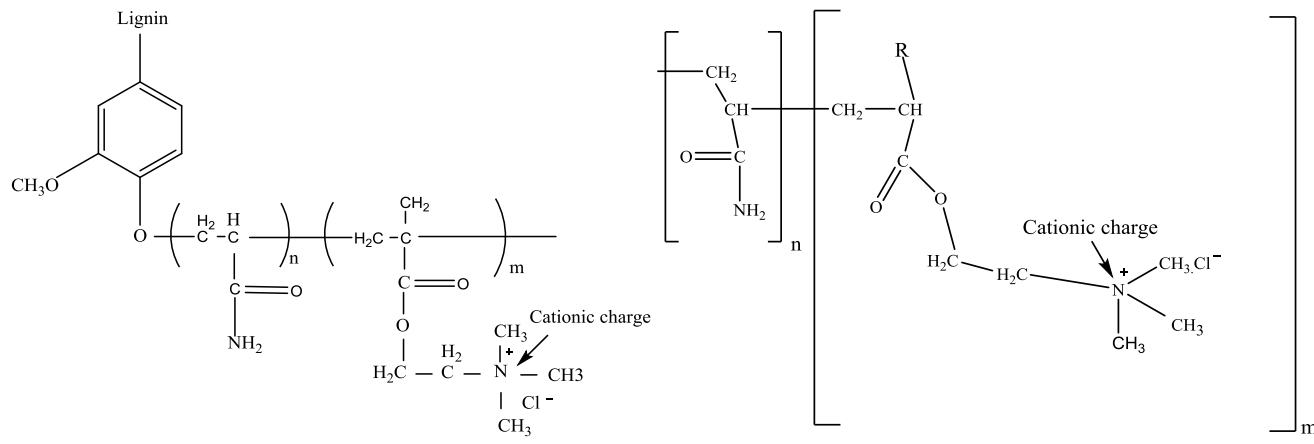

(a) Kraft lignin-acrylamide (Hasan and Fatehi, 2018)

(b) polyacrylamide (Craciun et al., 2015)

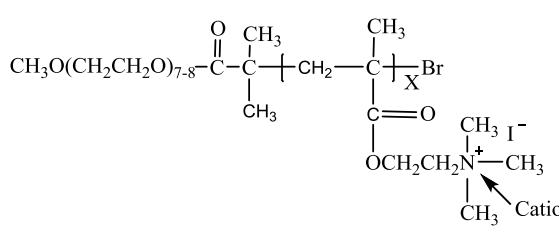

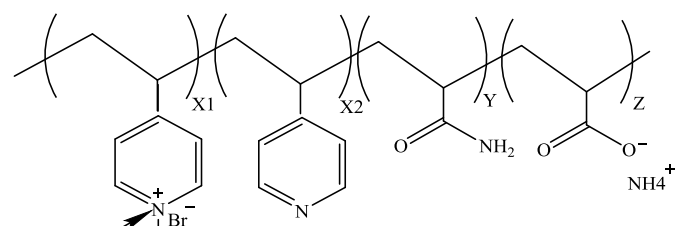

(c) Tertiary Amine Methacrylate (Alemdar and Bütün, 2005) (d) poly(acrylamide-co-(N-octyl-4-vinylpyridinium bromide)) (Mansri et al., 2019)

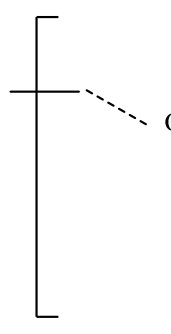

(e) Chitosan (Postnova et al., 2015)

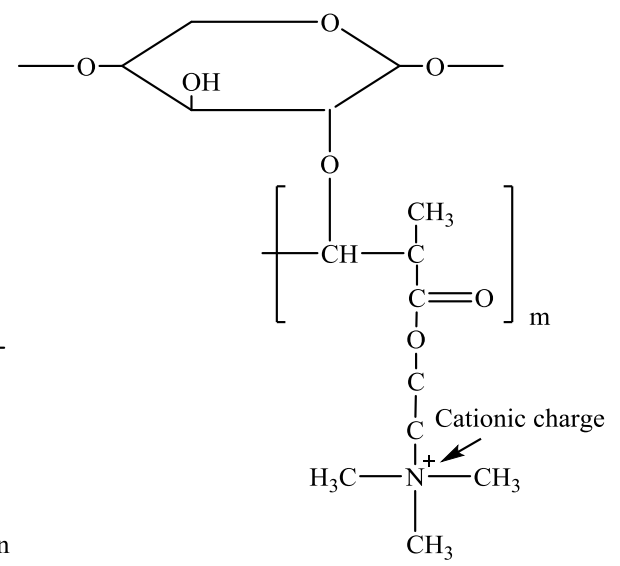

(f) xylan-METAC (Wang et al., 2016)

Fig. 3. Chemical structures of the cationic polyelectrolytes used in recent studies relevant to the interaction between smectites and non-ionic polyelectrolytes

The surface charge density of montmorillonite and the molecular weight of cationic polyelectrolytes influence the adsorption and flocculation behavior of aqueous montmorillonite dispersion (Shaikh et al., 2017b). The floc sizes increased with increasing surface charge density and molecular weight of cationic polyelectrolytes. For example, interactions between the two kinds of cationic kraft lignin-acrylamide (KAD), of molecular weight 168,200 g/mol (KAD-1) and $103,000 \mathrm{~g} / \mathrm{mol}$ (KAD-2) with montmorillonite has proved to be interact differently (Hasan and Fatehi, 2018). Although the two KADs had similar charge density $(1.15 \mathrm{mmol} / \mathrm{g}), \mathrm{KAD}-1$, with a higher molecular weight, resulted in higher adsorption and bigger floc sizes than KAD-2. The KAD-1 and KAD-2 reached the saturation adsorption levels of 1.08 and $0.99 \mathrm{mg} / \mathrm{g}$ on montmorillonite, respectively. The KAD-1 would have a longer chain, therefore higher chance for tail and loop configuration on montmorillonite particles during adsorption of particles from the dispersion, which would in turn promote KAD-1 bridging. In addition, higher the charge density 
of cationic KAD, greater is the adsorption and flocculation. For instance, an increase in the charge density of a cationic KAD (KAD-1=2.13 meq/g, KAD-2=1.29 meq/g) promoted its adsorption onto montmorillonite due to stronger electrostatic interactions between KAD and montmorillonite particles. In case of montmorillonite, the adsorption for KAD-1 and KAD-2 was 1.83 and 1.63 $\mathrm{mg} / \mathrm{g}$, respectively. Similar phenomenon have been observed in the interactions for other polyelectrolytes interacting with montmorillonite in water. (Wang et al., 2016) The flocculation efficiency of cationic xylan-2-(methacryloyloxy)ethyl] trimethyl ammonium chloride (xylan-METAC) copolymers with different charge density and different molecular weights were compared where CMX1 and CMX2 has +1.8 and +2.4 meq/g with their molecular weights 88986 and $102545 \mathrm{~g} \mathrm{~mol}^{-1}$, respectively. CMX2 was acted as a more efficient flocculant than CMX1 as CMX2 adsorbed and removed more efficiently by montmorillonite particles from the aqueous dispersion. The adsorption of CMX1 and CMX2 was 0.73 and $0.85 \mathrm{mg} / \mathrm{g}$ on montmorillonite particles, respectively. It was reported that polymers with a higher charge density would adsorb more on clay particles. CMX2 also changed the zeta potential and turbidity of the aqueous montmorillonite dispersion more remarkably than CMX1, which was attributed to its higher charge density and molecular weight.

In addition, different polyelectrolytes have different interactions with montmorillonite in water. Polyelectrolytes such as 3,6-ionene (Campos and Tcacenco, 2015) interaction with the montmorillonite surface takes place by Coulombic forces between the positively charged sites of 3,6- and negatively charged montmorillonite surface. The 3,6-ionene caused the basal spacing of the commercial montmorillonite to increase from 1.5 to $3.5 \mathrm{~nm}$. Polyelectrolytes such as polycationic quaternary amine polymer F25 (Blachier et al., 2009), polyethyleneimine (PEI) (Oztekin, 2017) and poly(acrylamide-co-(N-octyl-4-vinylpyridinium bromide)) (AM5/VP5C8Br) were used to flocculate aqueous montmorillonite dispersion. The interactions between $\mathrm{AM} 5 / \mathrm{VP} 5 \mathrm{C} 8 \mathrm{Br}$ and montmorillonite particles in dilute aqueous dispersions (Mansri et al., 2019) allowed the adsorption of the montmorillonite particles on the AM5/VP5C8Br chains, that occurred initially by the hydrophobic interaction. The electrostatic attraction between the positively charged sites on the AM5/VP5C8Br and the negative montmorillonite particles dispersion can eventually lead to patches and flocculation. The AM5/VP5C8Br chain conformation was affected by the $\mathrm{pH}$ of medium, thereby influencing the flocculation. The AM5/VP5C8Br chains adopted a flat conformation at $\mathrm{pH}<4$ due to important repulsive electrostatic forces by the cationic 4VP moieties (Fig.4). In the range of $4<\mathrm{pH}<8$, the charge density of the AM5/VP5C8Br related to acid addition is very low, preventing the extension of the AM5/VP5C8Br chains. At $\mathrm{pH}>8$, a turbidity removal becomes smaller than for $\mathrm{pH}<4$ and $4<$ $\mathrm{pH}<8$, which was related to the compact pelote conformation adopted by the AM5/VP5C $8 \mathrm{Br}$ chains. The hydroxide groups $(\mathrm{OH})$ of aqueous medium played an important role in screening phenomena of positively charged sites on the AM5/VP5C $8 \mathrm{Br}$ chains. Thus, the flat conformation 
assists the formation of flocs by adsorption between $\mathrm{AM} 5 / \mathrm{VP} 5 \mathrm{C} 8 \mathrm{Br}$ and montmorillonite particles, where the best flocculation was observed for dilute aqueous dispersions at $\mathrm{pH}<4$.
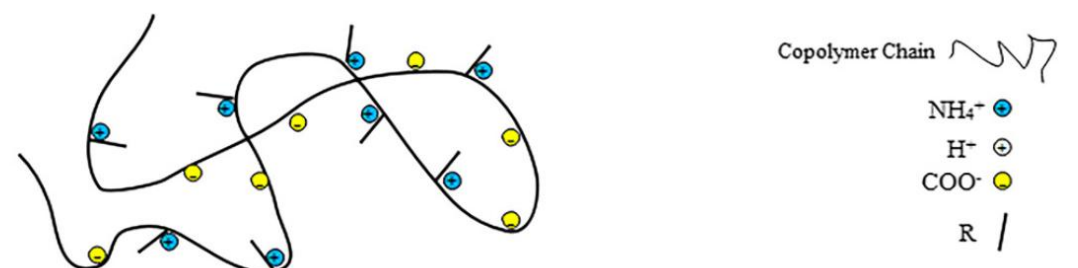

\section{$\mathrm{R} /$}

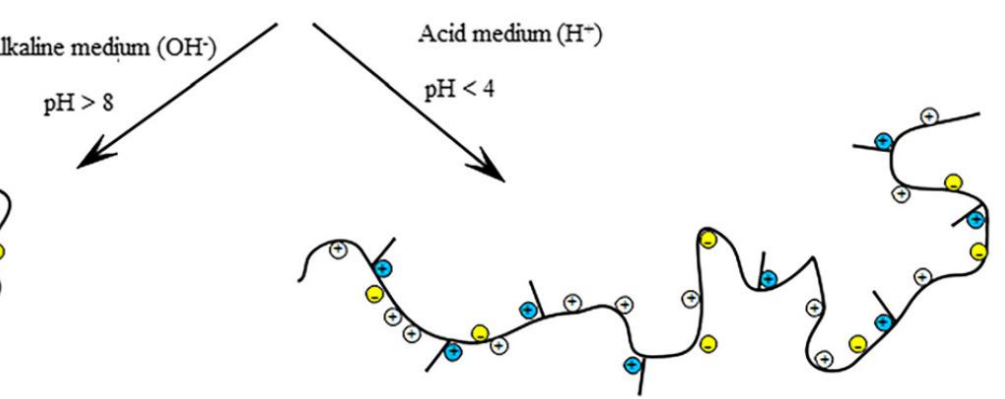

Fig.4 Proposed conformation of the AM5/VP5C8Br chain at different $\mathrm{pH}$ in aqueous medium. (Reprinted by permission from Taylor \& Francis: (Mansri et al., 2019), copyright 2019).

\subsection{Saponite}

Chitosan, a natural linear cationic polysaccharide containing free amino groups, has been intercalated into saponite (Shchipunov et al., 2012a; Shchipunov et al., 2012b; Budnyak et al., 2016; Mishchenko et al., 2016). Budnyak et al. (2016) demonstrated an effective way to produce chitosan-saponite composites by impregnating $20 \mathrm{~g}$ of saponite in $285 \mathrm{ml}$ of chitosan solution, with a concentration of $7 \mathrm{mg} / \mathrm{ml}$ in acetic acid ( $\mathrm{pH}$ 2.6). Chitosan has higher affinity for the surface of saponite due to the interaction between protonated amino groups of chitosan and dissociated saponite hydroxyl groups in water. The interactions also involve the electrostatic interaction and hydrogen binding (Fig. 5a). The interaction between saponite and chitosan gradually increased the viscosity and finally hydrogelation, leading to forming saponite/chitosan hydrogel nanocomposites (Fig. 5b) (Zhou et al., 2019b). Budnyak et al. (2016) studied the adsorption properties of chitosan-saponite composites for metal ions such as $\mathrm{Cu}(\mathrm{II}), \mathrm{Zn}$ (II), $\mathrm{Fe}(\mathrm{III}), \mathrm{Cd}(\mathrm{II})$, and $\mathrm{Pb}$ (II). The results shows that the interactions between saponite and cationic chitosan improved the adsorption of cations $\mathrm{Cu}(\mathrm{II}), \mathrm{Zn}$ (II), $\mathrm{Fe}(\mathrm{III}), \mathrm{Cd}(\mathrm{II})$, and $\mathrm{Pb}$ (II) due to excellent sorption properties of chitosan-saponite composites and available adsorption sites in the interlayer space, large surface area with narrower channels inside. Therefore, chitosan-saponite composites were employed to adsorb the heavy metals and toxic dyes in wastewater treatment. 
(a)

(b)
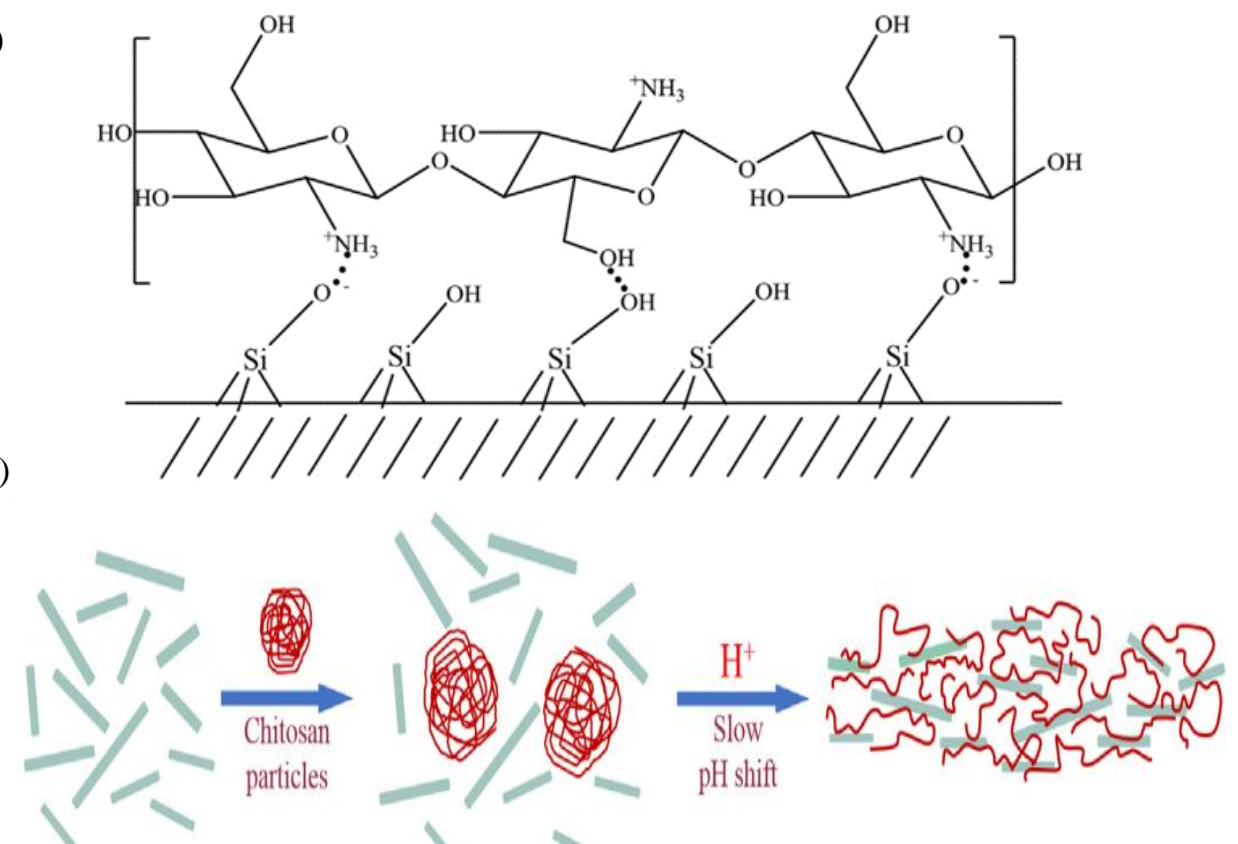

Fig. 5. (a) Schematic diagram showing that the interactions between chitosan and saponite involve the electrostatic interaction and hydrogen bonding (Budnyak et al., 2016); (b) Schematic drawing of main stages of formation of monolithic hydrogel by chitosan and saponite. (Shchipunov et al., 2009) - Reproduced by permission of The Royal Society of Chemistry.

\section{Table 1}

Recent typical studies on the interaction between smectites and cationic polyelectrolytes

\begin{tabular}{|c|c|c|c|c|}
\hline $\begin{array}{l}\text { Cationic } \\
\text { polyelectrolytes }\end{array}$ & Smectite & Conditions & Interaction & References \\
\hline PAM & Montmorillonite & $\begin{array}{l}\text { PAM: } 2.0 \% \text { v/v; } \\
\text { Montmorillonite: } 100 \mathrm{ml} \text {; } \\
\text { The system: pH } 9 .\end{array}$ & $\begin{array}{l}\text { Strong adsorption affinity; } \\
\text { Cause montmorillonite surface charge } \\
\text { reversal; } \\
\text { Floc sizes increased. }\end{array}$ & $\begin{array}{l}\text { (Shaikh et } \\
\text { al., 2017b) }\end{array}$ \\
\hline AM5/VP5C8Br & Montmorillonite & $\begin{array}{l}\text { AM5/VP5C8Br: } 1-5 \text { ppm; } \\
\text { Montmorillonite: } 400 \mathrm{ml} \text {; } \\
\text { The system: pH } 2 \text {. }\end{array}$ & $\begin{array}{l}\text { Flocculation; } \\
\text { Hydrophobic. }\end{array}$ & $\begin{array}{l}\text { (Mansri et } \\
\text { al., 2019) }\end{array}$ \\
\hline xylan-METAC & Montmorillonite & $\begin{array}{l}\text { Xylan-METACL: } 2 \text { or } 3 \text { mol } \\
\text { mol }^{-1} \text {; } \\
\text { Montmorillonite concentration: } 1 \\
\text { g L }^{-1} \text {; } \\
\text { pH } 7 \text {. }\end{array}$ & $\begin{array}{l}\text { Zeta potential and turbidity were } \\
\text { changed; } \\
\text { Higher charge density and molecular } \\
\text { weight. }\end{array}$ & $\begin{array}{l}\text { (Wang et al., } \\
\text { 2016) }\end{array}$ \\
\hline Chitosan & Saponite & $\begin{array}{l}\text { Chitosan content: } 285 \mathrm{ml} \text {; } \\
\text { Saponite content: } 20 \mathrm{~g} \text {; } \\
\text { Acetic acid concentration: } 7 \\
\mathrm{mg} / \mathrm{ml} \text {; } \\
\text { pH 2.6. }\end{array}$ & $\begin{array}{l}\text { Electrostatic; } \\
\text { Hydrogen binding. }\end{array}$ & $\begin{array}{l}\text { (Budnyak et } \\
\text { al., 2016) }\end{array}$ \\
\hline RhPEG & Saponite & $\begin{array}{l}\text { RhPEG content: } 0.05-0.25 \mathrm{wt} \% \text {; } \\
\text { Saponite } 0.1 \mathrm{~g} \mathrm{~L}^{-1}\end{array}$ & $\begin{array}{l}\text { Irreversible adsorption; } \\
\text { Two types of bonding between the }\end{array}$ & $\begin{array}{l}\text { (Sas et al., } \\
\text { 2017) }\end{array}$ \\
\hline
\end{tabular}


RhPEG and the saponite surface.

\begin{tabular}{|c|c|c|c|c|}
\hline Poly(NIPAm) & Saponite & Saponite/Poly(NIPAm: $11 \mathrm{wt} \%$. & $\begin{array}{l}\text { Dispersion; } \\
\text { Adsorption. }\end{array}$ & $\begin{array}{l}\text { (Nakamura } \\
\text { and Ogawa, } \\
\text { 2013) }\end{array}$ \\
\hline PS & Na- saponite & $\begin{array}{l}\text { PS: } 1.2 \mathrm{~g} \text { in } 100 \mathrm{ml} \text { water; } \\
\text { Saponite content: } 4-30 \mathrm{wt} \% \text {; } \\
\text { Co-stabilizer: hexadecane and } \\
\text { AIBN. }\end{array}$ & $\begin{array}{l}\text { Formation of asymmetric PS/saponite } \\
\text { composite nanoparticles; } \\
\text { Hydrophobically. }\end{array}$ & $\begin{array}{l}\text { (Tong and } \\
\text { Deng, 2013) }\end{array}$ \\
\hline
\end{tabular}

\section{Anionic polyelectrolytes}

\subsection{Montmorillonite}

Anionic polyelectrolytes are bearing negatively charged functional groups, commonly - $\mathrm{COO}^{-}$, $-\mathrm{O}-\mathrm{SO}_{3}{ }^{2-},-\mathrm{SO}_{3}{ }^{2-},-\mathrm{O}-\mathrm{CS}^{2-},-\mathrm{O}-\mathrm{PO}_{3}{ }^{2-},-\mathrm{PO}_{3}{ }^{2-}$. The interaction between smectites and anionic polyelectrolytes seems impossible as both entities are bearing negatives charges. Yet researchers have explored that the interactions of smectite and anionic polyelectrolyte. The anionic polyelectrolyte includes copolymer of acrylamide, 2-acrylamido-2-methylpropane sulfonic acid (AM-AMPS) and a terpolymer of acrylamide, 2-acrylamido-2-methylpropane sulfonic acid, and N-Vinylpyrrolidone (AM-AMPS-NVP) (Ahmad et al., 2018), anionic polyacrylamide (APAM) (Heller and Keren, 2002), sulfonated polyacrylamide (SPA) (Oliyaei et al., 2015), anionic polyacrylamide-acrylate copolymer (Mpofu et al., 2004) (Fig. 6). The interactions can be divided into two types: an electrostatic interaction between the anionic polyelectrolyte chains and the positive charges on the edges of the smectite particles; a repulsive interaction between the negative smectite charge and the polyelectrolytes (Gumfekar and Soares, 2018). The smectite-anionic polyelectrolyte interactions in aqueous dispersion depend on molecular weight, polyelectrolyte concentration, size, surface charge and concentration of the smectite particles in

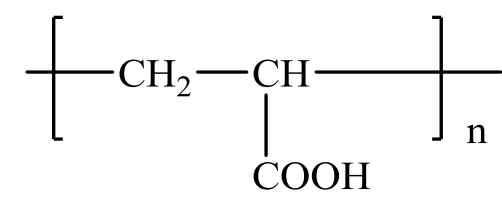

(a) Poly(acrylic acid)

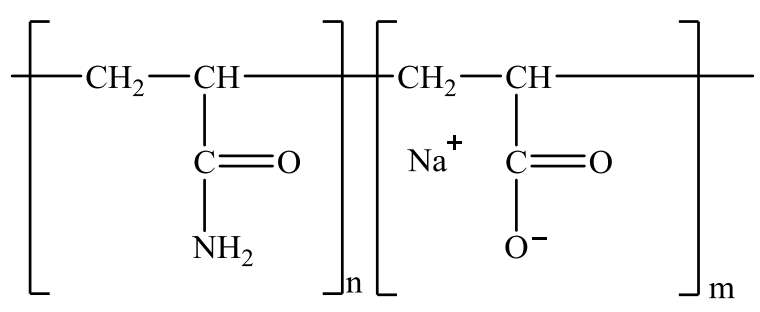

(b) polyacrylamide (Ewanek, 2008) 
<smiles>CCCCC(CC(CCC)C(=O)NC(C)(C)C[Se]O[Na])C(N)=O</smiles>

(c) Sulfonated polyacrylamide (Ehsan et al., 2017)

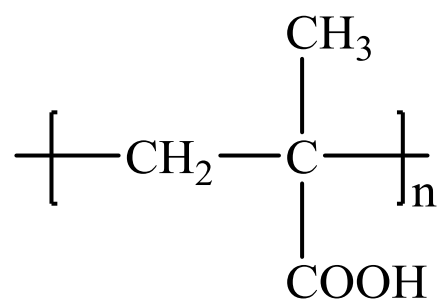

(d) Polymethacrylic acid

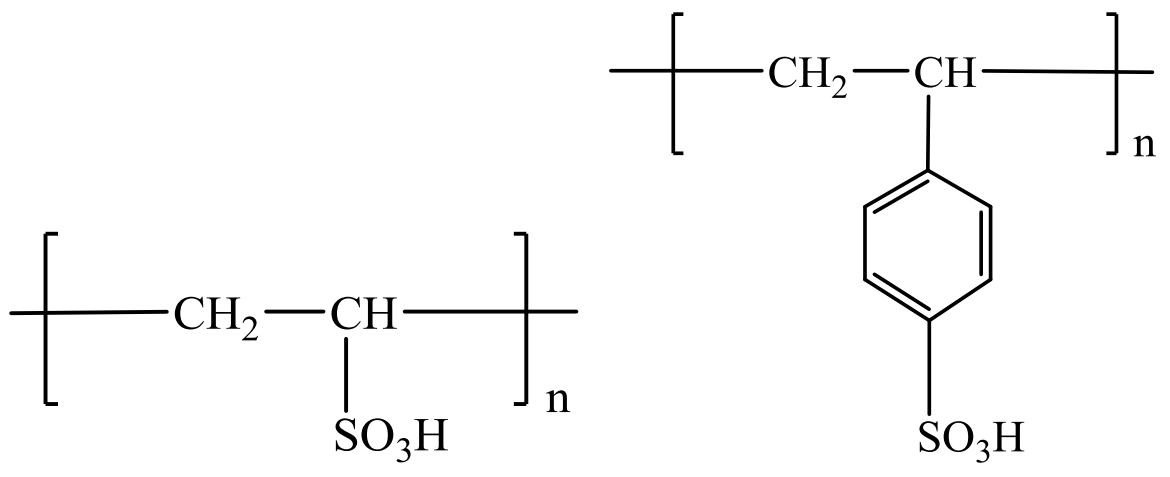

(e) Polyvinyl sulfonic acid

(f) Poly(styrenesulfonic acid)<smiles>COC(CC(C)(C)CC(C(=O)O)C(C(=O)O)C(C(=O)O)C(C)(C)C)C(C(=O)O)C(CC(C)(C)C)c1ccccc1</smiles>

(g) Styrene-maleic acid copolymer

(h) Methyl vinyl ether-maleic acid copolymer<smiles>CC(C)(C)CC(C(=O)O)C(C(=O)O)C(CC(C)(C)C(C)(C)OP(=O)(O)C(C)(C)C)C(=O)O</smiles>

(i) Acrylic acid-maleic acid copolymer

(j) Polyphosphoric acid

Fig.6. Chemical structures of the non-ionic polyelectrolytes used in recent studies relevant to the interaction between smectites and non-ionic polyelectrolytes

The interaction between smectites and anionic polyelectrolytes is often used for altering adsorption, flocculation, and rheological behavior (Kafashi et al., 2017; Diouri et al., 2018) (Table 2). The addition of anionic polyelectrolyte into water-based drilling fluids can compensate for deficiencies of montmorillonite-based drilling fluids that can lead modification of the rheological properties. For example, polyanionic cellulose (PAC) (Kelessidis et al., 2013), sodium carboxymethyl cellulose and xanthan gum (XG) (de Souza et al., 2017) have been added into water-based drilling fluids to obtain the desired rheological properties. The addition of copolymer and terpolymer, a copolymer of acrylamide and 2-acrylamido-2-methylpropane sulfonic acid 
(AM-AMPS) (P1) and a terpolymer of acrylamide, 2-acrylamido-2-methylpropane sulfonic acid, and N-vinylpyrrolidone (AM-AMPS-NVP (P2)) into aqueous montmorillonite dispersion can enhanced their rheological properties (viscosity and shear stress). The montmorillonite/polymer dispersions has higher viscosity and shear stress compared to the montmorillonite dispersions at $1 / \mathrm{s}$ shear rate at $25^{\circ} \mathrm{C}$ in deionized water (Ahmad et al., 2018). And the montmorillonite/P2 dispersion has higher viscosity and shear stress compared to the montmorillonite/P1 dispersion at $1 / \mathrm{s}$ shear rate at $25^{\circ} \mathrm{C}$ in deionized water. This is because the polymer P2 has three different moieties with negative charges along the backbone whereas the polymer P1 has two moieties with negative charges (Fig.7). Therefore, there were stronger electrostatic repulsive interactions between polymer P2 and montmorillonite layers than for polymer P1, this stronger electrostatic repulsion gives the montmorillonite/P2 dispersion better rheology. In addition, Chalah et al. (2018) shows addition of the anionic polyelectrolyte xanthan gum into the 5\% aqueous montmorillonite dispersion increased the viscosity of the water-montmorillonite dispersion. These recent findings prove the rational usage of different types of anionic polyelectrolytes additives in water-based drilling muds.

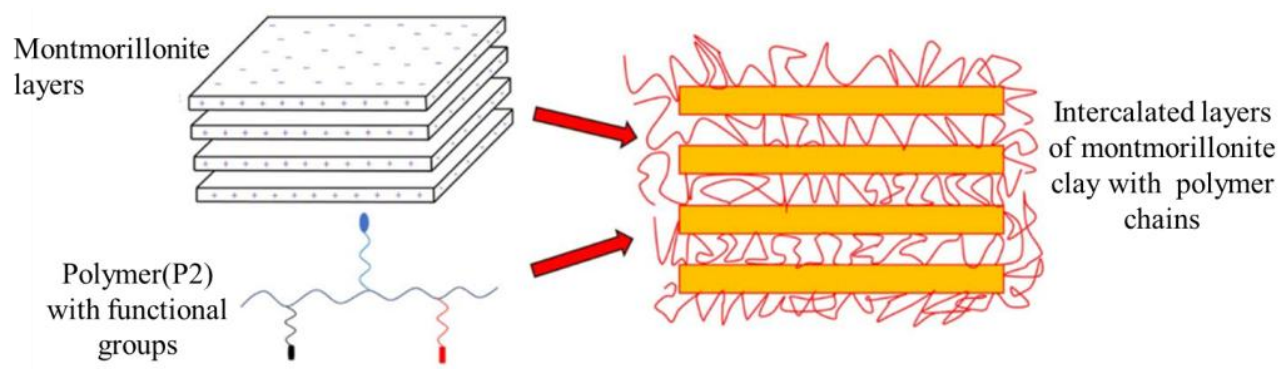
groups

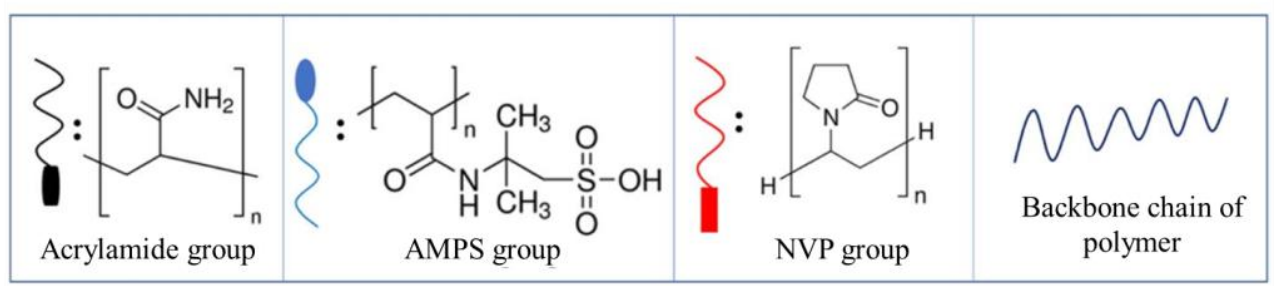

Fig. 7. Schematic diagram of montmorillonite/Polymer (P2) interactions. Reprinted from (Ahmad et al., 2018), copyright (2018), with permission from Elsevier.

High molecular weight and high degrees of hydrolysis of anionic PAM in aqueous montmorillonite dispersion could be more effective in stabilizing montmorillonite aggregate than those with lower molecular weight and degrees of hydrolysis (Heller and Keren, 2002). Three possibilities for the interaction between PAM and montmorillonite particles may existing: (i) by anion exchange between the surface hydroxyl group of the montmorillonite and the carboxyl anion of PAM; (ii) by hydrogen bonding between the surface hydroxyl group and $\mathrm{C}=\mathrm{O}$ of the PAM; (iii) by making a bridge involving divalent ions derived from electrostatic forces. Güngör 
strong bond), while PAM with Ca-montmorillonite and Na-montmorillonite shows additional adsorption bands at 1653 and $3433 \mathrm{~cm}^{-1}$ which indicating that PAM molecules and montmorillonite particles were interacting. The PAM molecule were loosely bound and interacts near the surface and/or into the interlayers of the montmorillonite. The dominant electrostatic repulsions between the anionic PAM functional groups and the negative surface charge of montmorillonite were responsible for the lower adsorption affinity of anionic PAM towards montmorillonite particles (Barany et al., 2009; Shaikh et al., 2017b). The same amounts of anionic PAM was added to the aqueous Na-montmorillonite dispersion and the aqueous $\mathrm{Ca}$-montmorillonite dispersion under the same conditions (2\% $\mathrm{Ca}-$ and $\mathrm{Na}-$ montmorillonite-water systems), the aqueous Na-montmorillonite dispersion and the aqueous Ca-montmorillonite dispersion showed different rheological behaviors (N. Güngör, 2001). The anionic PAM has a flocculation effect in the aqueous Ca-montmorillonite dispersion whereas it has a de-flocculation effect in aqueous Na-montmorillonite dispersion as $\mathrm{Ca}^{2+}$ has a strong tendency to form face/face contacts, which can cause defects in the edge (+)/face (-) network that promote its fragmentation. In the absence of $\mathrm{Ca}^{2+}$, the "house of cards" would decompose at edge charge densities, so $\mathrm{Ca}^{2+}$ ions can help the formation of bridging flocculation.

PAM/montmorillonite dispersion has important role in several industries, including paper, water treatment, enhanced oil recovery and drilling (Khoshniyat et al., 2012). Sulfonated polyacrylamide (SPA) has higher thermal stability than standard hydrolyzed PAM and is commercially used as stabilizer in oil fields up to $120^{\circ} \mathrm{C}$ (Oliyaei et al., 2015). The stability of aqueous Na-montmorillonite dispersions in the absence of SPA, were due to the electrostatic interactions. The preseance of SPA, modified the Na-montmorillonite particle-particle interactions as few SPA chains can be adsorbed onto the Na-montmorillonite particles surface via hydrogen bonds between the oxygen atoms of Na-montmorillonite and the protons of the amide groups of SPA, resulting in steric stability. However, there were repulsion between the negative layers of Na-montmorillonite and the anionic groups of SPA, therefore, the two interactions, adsorption and repulsion, result in dispersion stability.

Earlier, anionic polyacrylamide-acrylate copolymer proved effective in flocculating montmorillonite dispersions (Mpofu et al., 2004). Both montmorillonite particles and PAM molecules are negatively charged $(\mathrm{pH}=7.5)$, and the main driving force for adsorption was hydrogen bonding between the silanol and aluminol $\mathrm{OH}$ groups at the montmorillonite particle surfaces, particularly the edge faces and the amide $\left(-\mathrm{CONH}_{2}\right)$ groups (Lewis base) of the copolymer. The longer the length of the copolymer, the higher flocculation efficiency of the montmorillonite dispersion. The concentration of the anionic polyacrylamide-acrylate copolymer flocculant increases, the size of the particles decreases, and the affinity and adsorption density increase. Hence, polyacrylamide-acrylate copolymer is normally used as a flocculant in industry for montmorillonite dispersions. 
Recent typical studies on the interactions between smectites and anionic polyelectrolytes

\begin{tabular}{|c|c|c|c|c|}
\hline $\begin{array}{l}\text { Anionic } \\
\text { polyelectrolytes }\end{array}$ & Type of smectite & Conditions & Interaction & References \\
\hline PAM & Montmorillonite & $\begin{array}{l}\text { PAM: } 2.0 \% \text { v/v; } \\
\text { Montmorillonite: } \\
100 \mathrm{ml} \text {; } \\
\text { The system: pH } 9 .\end{array}$ & $\begin{array}{l}\text { Lower adsorption } \\
\text { capacities; } \\
\text { Floc sizes increased. }\end{array}$ & $\begin{array}{l}\text { (Shaikh et } \\
\text { al., 2017b) }\end{array}$ \\
\hline AM-AMPS & Montmorillonite & $\begin{array}{l}\text { Montmorillonite } \\
\text { content: } 5 \mathrm{wt} \% \text {; } \\
\text { AM-AMPS content: } \\
0.25 \mathrm{wt} \% \text {; } \\
\text { Temperatures: } 25^{\circ} \mathrm{C} \text {, } \\
85^{\circ} \mathrm{C}\end{array}$ & $\begin{array}{l}\text { Electrostatic repulsive } \\
\text { forces; } \\
\text { Enhanced the rheological } \\
\text { properties. }\end{array}$ & $\begin{array}{l}\text { (Ahmad et } \\
\text { al., 2018) }\end{array}$ \\
\hline $\begin{array}{l}\text { AM-AMPS-NV } \\
\mathrm{P}\end{array}$ & Montmorillonite & $\begin{array}{l}\text { Montmorillonite } \\
\text { content: } 5 \mathrm{wt} \% \\
\text { AM-AMPS-NVP } \\
\text { content: } 0.25 \mathrm{wt} \% \text {; } \\
\text { Temperatures: } 25^{\circ} \mathrm{C} \text {, } \\
85^{\circ} \mathrm{C}\end{array}$ & $\begin{array}{l}\text { Electrostatic repulsive } \\
\text { forces; } \\
\text { Enhanced the rheological } \\
\text { properties. }\end{array}$ & $\begin{array}{l}\text { (Ahmad et } \\
\text { al., 2018) }\end{array}$ \\
\hline SPA & Montmorillonite & $\begin{array}{l}\text { Montmorillonite } \\
\text { content: } 0.5 \sim 3 \mathrm{wt} \% \text {; } \\
\text { SPA content: } 0 \sim 0.4 \\
\text { wt } \% \text {. }\end{array}$ & $\begin{array}{l}\text { Increased the Z-average } \\
\text { particle sizes. }\end{array}$ & $\begin{array}{l}\text { (Oliyaei et } \\
\text { al., 2015) }\end{array}$ \\
\hline SPA & Hectorite & ---- & $\begin{array}{l}\text { Hydrogen bonding; } \\
\text { Ionic interaction. }\end{array}$ & $\begin{array}{l}\text { (Ehsan et } \\
\text { al., 2017) }\end{array}$ \\
\hline PAAS & Hectorite & $\begin{array}{l}\text { Hectorite content: } \\
10 \mathrm{wt} \% \text {; } \\
\text { PAAS content: } 3.5 \\
\text { wt } \% \text {; } \\
\text { Molecular mass: } 2.3 \\
\times 10^{5} \text {; } \\
\text { Dispersant: } 0.25 \\
\text { wt } \% \text { TSPP; }\end{array}$ & Adsorbed. & $\begin{array}{l}\text { (Takeno and } \\
\text { Nakamura, } \\
\text { 2019) }\end{array}$ \\
\hline
\end{tabular}

AM-AMPS: acrylamide and 2-acrylamido-2-methylpropane sulfonic acid

AM-AMPS-NVP: acrylamide, 2-acrylamido-2-methylpropane sulfonic acid, and N-Vinylpyrrolidone PAM: Polyacrylamide

PAAS: Polyethylene oxide

SPA: Sulfonated polyacrylamide

\subsection{Saponite and hectorite}

Saponite can easily delaminate in water to form a sol or hydrogel and has been widely used in many products ranging in cosmetics, paints and adhesives (Zhou et al., 2019b). In most cases of 
and polyelectrolytes in their system. However, details on such interactions remain unclear. Li et al. (2019a) studied the rheological behaviors of saponite sol-gel system, and reveal the interaction between saponite particles and the sodium polyacrylate (NaPA) by preparing saponite hydrogels with polyelectrolyte NaPA (Fig.8a). It was found that the NaPA incorporated saponite hydrogel was transformed to a sol due to the destruction of the house-of-card structure, and the saponite was well dispersed (Fig. 8aVI). A possible mechanism was also reported to explain the transformation of saponite hydrogel to sol. Firstly, the $\mathrm{PA}^{-}$instantaneous polarized in the electric field, which was formed near the saponite particles due to the surface charge. Then, it enters the saponite hydration layer to replace some of the original hydrated ions (Gong et al., 2018). Further, a strong chemical bond formed between the polarized $\mathrm{PA}^{-}$and the saponite particles due to stronger electrostatic attraction (Fig. 8bII). They also found that the stacking order of saponite particles was promoted after drying from the saponite-NaPA dispersion (Fig. 8aVII). This work suggested interactions between saponite particles and polyacrylates which might provide a help to tune the rheological performance of saponite sol-gel products and explore more functional saponite-based nanomaterials (Del Gaudio et al., 2018).

(a)

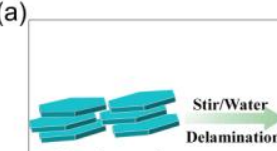
Raw Sap powder

(I)

(H) Hydrated $\mathrm{Na}^{+}$

$\odot$ Anion

$\ell$ Polarized PA

오

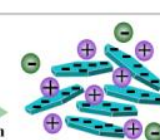

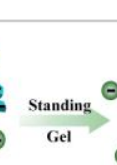

(II) $\ell$
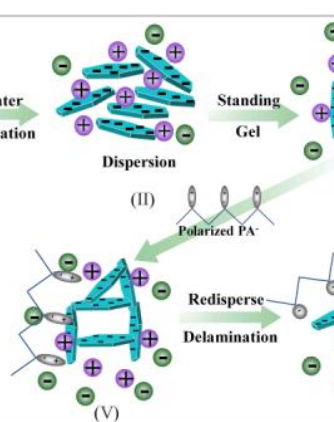

(III)
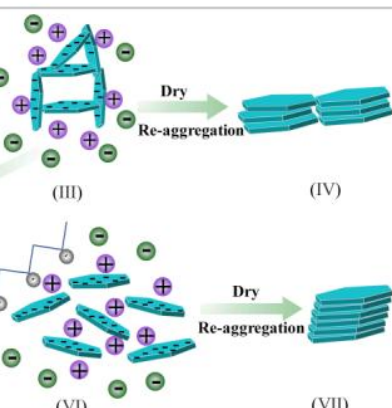

(b)

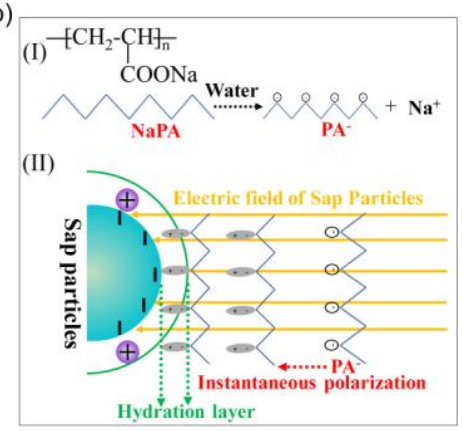

Fig.8. (a) Schematic illustration of saponite dispersion with/without added NaPA and reaggregation after drying: (I) Saponite dispersed in water to form (II) Saponite dispersion and (III) Saponite hydrogel; (V) interaction of the saponite hydrogel with polarized PA to form (VI) Saponite NaPA dispersion; (IV) Saponite-control and (VII) Saponite-NaPA reaggregated from Saponite hydrogel and Saponite-NaPA dispersion, respectively; (b) Illustrations of the interactions between saponite particles and NaPA: (I) Chemical formula of NaPA and schematic structure of $\mathrm{NaPA}$; (II) interaction between aggregated saponite particle and NaPA. Reprinted with permission from (Li et al., 2019a). Copyright 2019 American Chemical Society.

Hectorite, in particular the synthetic one, has been widely used in hydrogels (Du et al., 2016). In recent years, hydrogels with mechanical toughness have important application prospects in the fields of tissue engineering, health care, electronic skin, and soft robots, which have attracted great attention from researchers (Takeno and Nakamura, 2013; Takeno and Kimura, 2016; Takeno and Nakamura, 2019). Takeno and Kimura ( (2016) found that hydrogels prepared by simply blending an anionic NaPA with synthetic hectorite including a dispersant, tetrasodium pyrophosphate (TSPP), significantly improve the mechanical toughness of the resultant synthetic 
hectorite/NaPA/TSPP gel. Due to the addition of TSPP, synthetic hectorite particles were homogeneously dispersed in the gel, since TSPP prevented formation of house-of-cards structure by adsorption of pyrophosphate anions onto the positively charged edge of hectorite particles (Fig. 9a). Thus, the structural homogeneity in the hydrogel causes a significant increase of mechanical properties. In the case of anionic NaPA, carboxylate anion is also adsorbed on positively charged edge of synthetic hectorite particle (Takeno and Nakamura, 2013).

Molecular weight of NaPA in the synthetic hectorite/NaPA/TSPP gel system affects the tensile properties (Takeno and Kimura, 2016). Adding high molecular weight NaPA polyelectrolyte will improve the mechanical properties of hectorite / NaPA / TSPP gel system because the electrostatic interaction of high molecular weight NaPA with hectorite particles was stronger than for low molecular weight. In the case of the gel with high molecular weight NaPA, NaPA chains were capable of bridging adjacent synthetic hectorite particles. The long chain can keep cross-linking adjacent synthetic hectorite particles even under high elongation (Fig.9b). However, in the case of the gel with low molecular weight NaPA, when the gel was stretched, the short chains were not capable of bridging adjacent synthetic hectorite particles. Therefore, gel with low molecular weight NaPA has poor mechanical properties (Fig.9c). Hence, the use of high molecular weight polyelectrolytes is essential for producing blended hydrogels with mechanical toughness.

(a)
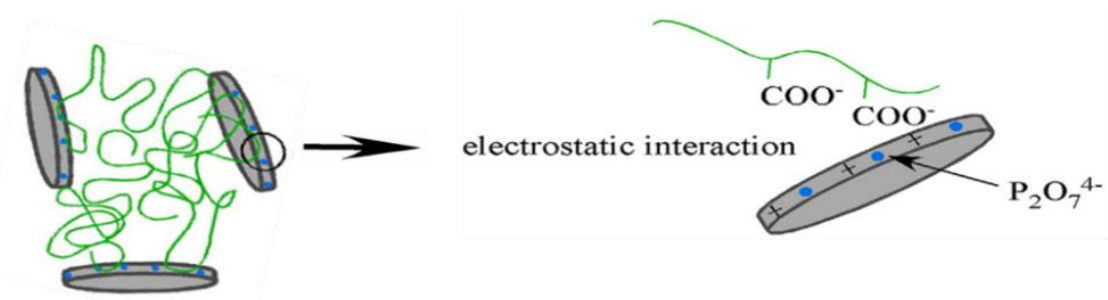

(b)

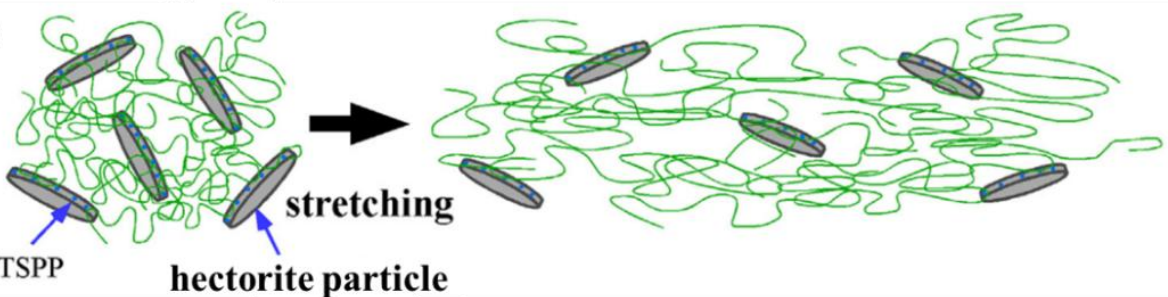

(c)
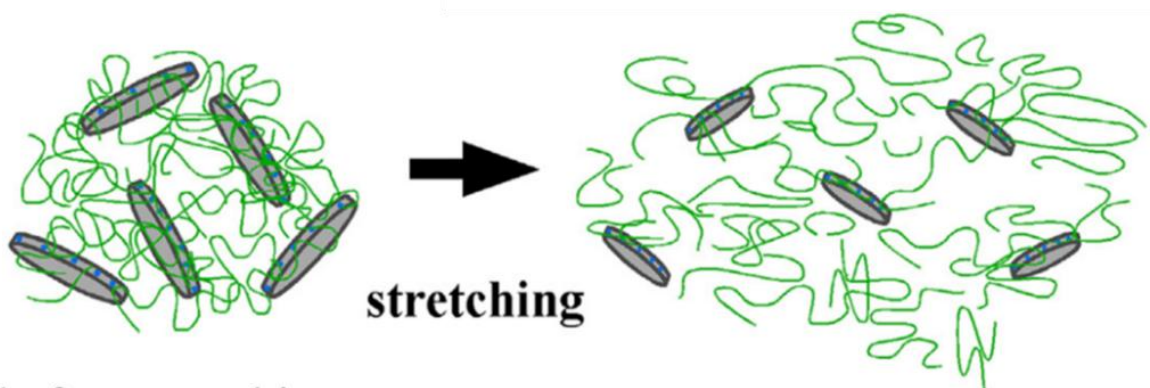

before stretching

after stretching

Fig.9 (a) A schematic representation of synthetic hectorite /NaPA/TSPP gel; and hydrogels composed of synthetic hectorite and NaPA with (b) high molecular weight $\left(3.50 \times 10^{6} \leq \mathrm{Mw} \leq 2.11 \times 10^{7}\right)$ and (c) with low 
molecular weight $\left(2.25 \times 10^{5} \leq \mathrm{Mw} \leq 1.55 \times 10^{6}\right)$ before and after stretching. Reprinted from (Takeno and Kimura, 2016). Copyright (2016), with permission from Elsevier.

Synthetic hectorite is a multifunctional cross-linker helping polyelectrolyte form networks. (Ehsan et al., 2017) prepared weak sulfonated polyacrylamide (SPA) nanocomposite hydrogels using synthetic hectorite nanoparticles and/or $\mathrm{Cr}^{3+}$ as crosslinker in saline solution. The interaction between the SPA and synthetic hectorite was a combination of hydrogen bonding and ionic interaction. The interactions between SPA and synthetic hectorite as well as the formation of SPA/ synthetic hectorite systems and $\mathrm{SPA} / \mathrm{Cr}^{3+} /$ synthetic hectorite systems are shown in Figure 10. The oxygen atoms on the synthetic hectorite surface with the amide proton of SPA may form hydrogen bonds, and the metal atoms on the synthetic hectorite surface may form a complex with the carboxylate oxygen of SPA (Li et al., 2008). Adsorption properties of SPA $/ \mathrm{Cr}^{3+} /$ synthetic hectorite systems increased when synthetic hectorite concentration was increased. This phenomenon may be due to the increased hydrogen bonding interaction of the amide group of the SPA with Si-OH and Si-O-Si groups, or ionic interaction of the synthetic hectorite surface (Abdurrahmanoglu and Okay, 2010). Both SPA $/ \mathrm{Cr}^{3+} /$ synthetic hectorite systems and SPA/synthetic hectorite systems interactions increased the storage modulus. The SPA crosslinked with $\mathrm{Cr}^{3+}$ and synthetic hectorite nanocomposite hydrogel exhibited better viscoelastic behavior than SPA polyelectrolyte or $\mathrm{SPA} / \mathrm{Cr}^{3+}$ hydrogels. Therefore, $\mathrm{SPA} / \mathrm{Cr}^{3+} /$ synthetic hectorite systems may be a potential option for field applications in hostile conditions due to better viscoelasticity and adsorption.

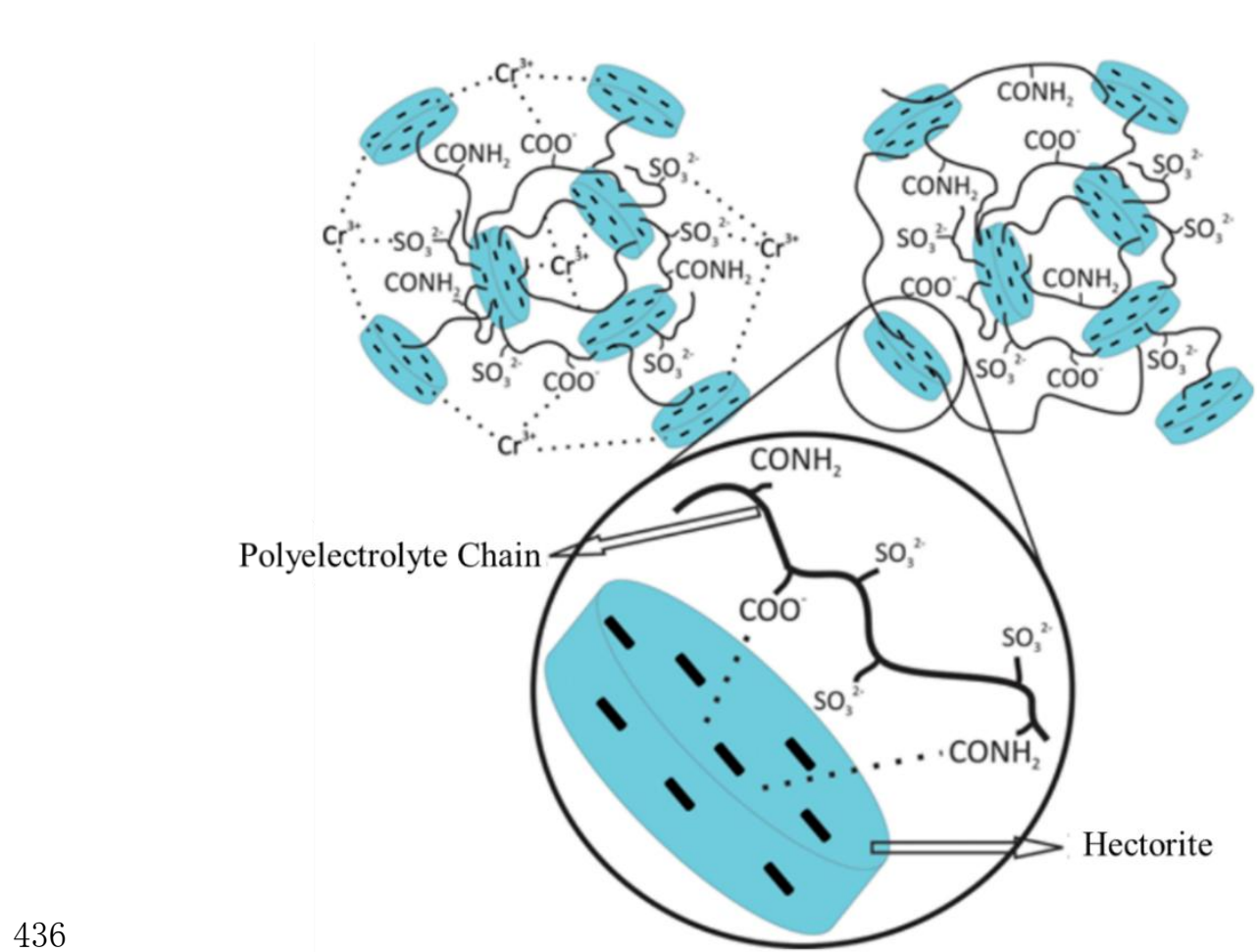

Fig.10 Schematic drawings of the formation of SPA/hectorite and SPA/ $\mathrm{Cr}^{3+} /$ hectorite hydrogels. Reprinted by permission from Springer Nature: Springer (Ehsan et al., 2017). Copyright 2017. 


\section{Amphoteric polyelectrolytes}

\subsection{Montmorillonite}

An amphoteric polyelectrolyte has both cationic and anionic groups distributed along the carbon chain. The solubility of amphoteric polyelectrolytes in water depends on the charge density, charge balance, asymmetry, and the chemical nature of the ionizable groups (Rabiee et al., 2014). The polymer bridging, charge neutralization, and polymer adsorption (Song et al., 2010) between the smectite and amphoteric polyelectrolytes promote flocculation in aqueous smectite-amphoteric polyelectrolytes dispersion, so amphoteric polyelectrolyte has been used in water treatment (Wang et al., 2019), and drilling fluid (Bai et al., 2015; Chu et al., 2013) (Table 3).

Gelatin, a natural amphoteric polyelectrolyte, due to biocompatibility, biodegradable properties, and no toxicity and availability, can potentially be a suitable substitute for the existing flocculants (Karimi et al., 2013). Gelatin can be effectively adsorbed on montmorillonite surfaces thereby changing the electrochemical nature of montmorillonite particle surface changes (Nazarzadeh et al., 2017). The adsorbed gelatin chains introduce bridging forces and steric forces in addition to electrostatic repulsion and Van der Waals attraction. In addition, the range of montmorillonite particle-particle interactions will also change with the thickness of the adsorbed layer, especially tail length of gelatin chains in the aqueous montmorillonite dispersion. Nevertheless, gelatin chains including cationic, anionic and uncharged monomer residues, the adsorption depends on the Coulomb interaction between the net charge on the carbon chain and the charged surface of montmorillonite (Kudaibergenov and Ciferri, 2007). If the excess charge on the gelatin chain is same as the charges of the montmorillonite surface, the Coulomb repulsion may inhibit adsorption. If the excess charges on the gelatin chain are opposite to those of the charges of the montmorillonite surface, the Coulomb interaction may promote adsorption.

Because amphoteric polyelectrolyte has both cationic and anionic groups distributed along the carbon chain, the content of anions and cations are needed to achieve specific purpose can be adjusted. For example, based on the ratio of cationic and anionic groups on the chains, amphoteric polyacrylamides exhibited variable flocculation efficiencies (Shaikh et al., 2017b) (Fig.11a). Polyacrylamides with a high ratio of cationic groups/anionic groups clearly displayed cationic behavior with high removal efficiency, while poor flocculation capabilities were observed with a low ratio of cationic-groups/anionic-groups. Hydrolyzed poly(acrylamide/dimethyl diallyl ammonium chloride) (HPAD), a polyampholyte containing quaternary ammonium groups, carboxylic acids, and amides has high ratio of cationic quaternary ammonium groups and specific carboxylic acids, and amides (Lin and Luo, 2018) (Fig.11b). The addition of HPAD amphoteric polyelectrolyte to the aqueous montmorillonite dispersion results in a strong electrostatic interaction between the charged chemical groups (quaternary ammonium groups, carboxylic acids, and amides) and montmorillonite particles, thus causing the formation of HPAD polymer bridges between adjacent montmorillonite particles and enlarges the charge imbalance of montmorillonite 
(Liu et al., 2016). Therefore, by introducing electrostatic repulsion, the HPAD helped montmorillonite maintain a broad particle size distribution. In return, broad particle size distribution contributed to the adsorption of HPAD on montmorillonite. Optimization of the composition of amphoteric polyelectrolyte could be useful for the future design and synthesis of filtration reducers in the oil and gas field.

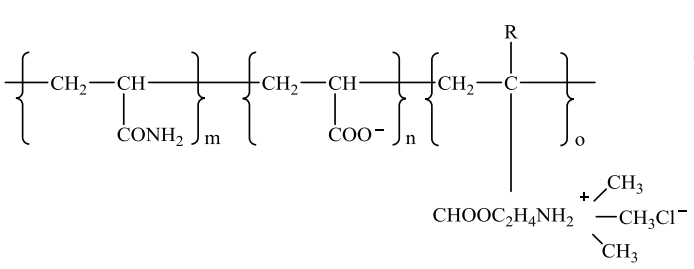

(a) $\operatorname{PAM}($ Shaikh et al., 2017a)

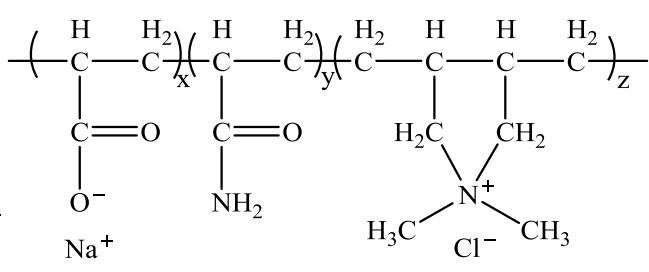

(b) HPAD (Lin and Luo, 2018)

Fig.11. Chemical structures of the non-ionic polyelectrolytes

\subsection{Saponite and hectorite}

The amphoteric polyelectrolyte can interact with saponite. In saponite-cationic PAM-anionic PAM-water mixtures, the cationic PAM was first adsorbed on the saponite particles by electrostatic and hydrogen bonding (Zhang et al., 2005). Then, the anionic PAM was adsorbed on the saponite particles by electrostatic or Van der Waals forces. The PAM molecule crosslinks with the cationic PAM adsorbed on the saponite particles in saponite aqueous solution to form a spatial network. The viscosity of the saponite-cationic PAM-anionic PAM-water mixtures was increased due to the interaction between anionic PAM and cationic PAM. Under the shear force, the spatial network was gradually destroyed. The structure can be reformed again when rested for a while due to thixotropy. This system can be used as an excellent water blocking agent for oil layers with large pores and high permeability.

Interaction between hectorite and amphoteric polyelectrolytes can improve the thermal stability of the drilling fluid. Huang et al. (2019) studied the interaction between hectorite and a terpolymer (AAD) by synthesizing through radical polymerization of acrylamide, 2-acrylamido-2-methylpropane sulfonic acid, and diallyldimethylammonium chloride monomers. The disk-shaped synthetic hectorite nanoparticles was well dispersed in aqueous terpolymer AAD dispersion, and the hectorite nanoparticles were establishing strong interactions between terpolymer AAD. The interactions included (Fig. 12): 1) electrostatic attractions between negatively charged synthetic hectorite surfaces and quaternary ammonium cationic groups of terpolymer AAD; 2) electrostatic attractions between positively charged synthetic hectorite edges and negatively charged sulfate groups of terpolymer AAD; and 3) possible hydrogen bonding between hydroxyl groups of synthetic hectorite and amide groups of terpolymer AAD. The interactions reduced the mobility of terpolymer $\mathrm{AAD}$ chains and also slowed down the degradation. This hectorite-terpolymer AAD system can increase the viscosity of drilling fluids. 

polyelectrolytes provided a novel strategy to develop high temperature-resistant drilling fluids for deep reservoir excavation (Akhtarmanesh et al., 2013; Li et al., 2015).
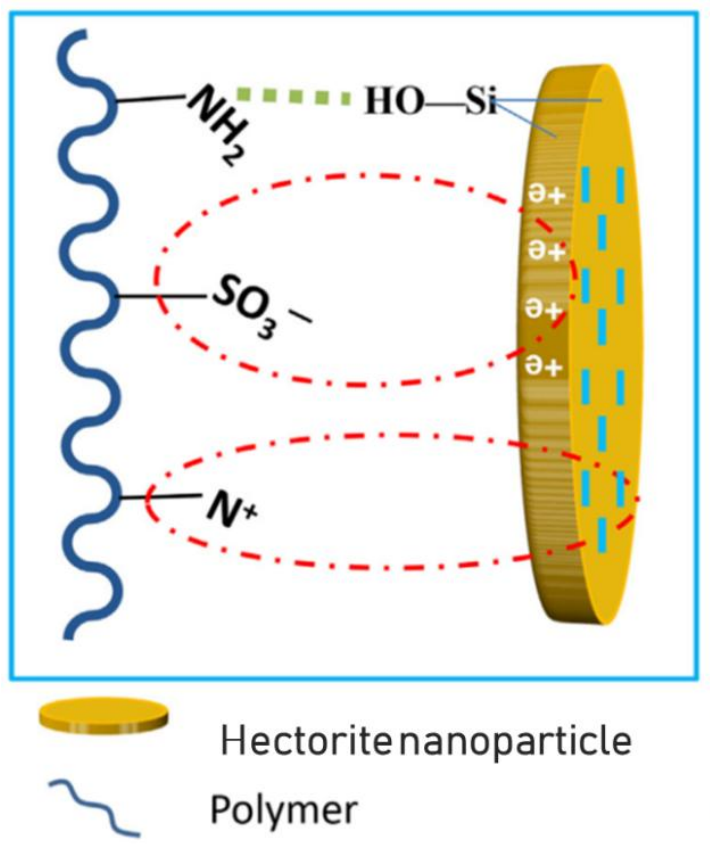

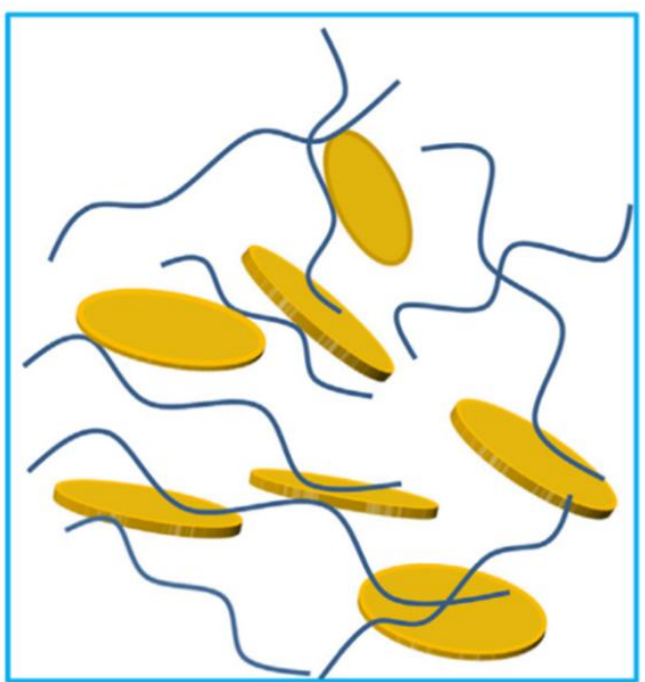

Hydrogen bonding

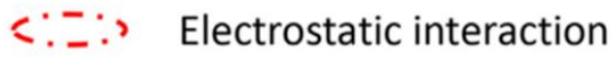

Fig.12 The proposed mechanism of the interactions between synthetic hectorite nanoparticles and terpolymer ADD. Reprinted from (Huang et al., 2019). Copyright 2019, with permission from Elsevier.

Table 3

Recent typical studies on the interaction between smectite and amphoteric polyelectrolytes.

\begin{tabular}{|c|c|c|c|c|}
\hline $\begin{array}{l}\text { Amphoteric } \\
\text { polyelectrolytes. }\end{array}$ & Type of smectite & Conditions & Interaction & References \\
\hline HPAD & Montmorillonite & $\begin{array}{l}\text { HPAD:0.5-2 wt } \% \text {; } \\
\text { Montmorillonite: } 5 \mathrm{wt} \% \text {; } \\
\mathrm{Na}_{2} \mathrm{SO}_{3}: 0.25 \mathrm{wt} \% \\
\mathrm{pH} 8 .\end{array}$ & $\begin{array}{l}\text { Adsorption; } \\
\text { Introducing electrostatic repulsion } \\
\text { and entropic repulsion. }\end{array}$ & $\begin{array}{l}\text { (Lin and } \\
\text { Luo, 2018) }\end{array}$ \\
\hline PAM & Montmorillonite & $\begin{array}{l}\text { PAM: } 2.0 \% \mathrm{v} / \mathrm{v} \text {; } \\
\text { Montmorillonite: } 100 \mathrm{ml} \text {; } \\
\text { The system: } \mathrm{pH} 9 .\end{array}$ & $\begin{array}{l}\text { Lower adsorption capacities due to } \\
\text { steric hindrance. }\end{array}$ & $\begin{array}{l}\text { (Shaikh et } \\
\text { al., 2017b) }\end{array}$ \\
\hline $\mathrm{PECT/CS}$ & Montmorillonite & $\begin{array}{l}\text { PECT/CS ratios: } 1: 1,1: 2 \text { and } \\
2: 1 ; \\
\text { Montmorillonite } \\
\text { concentration: } 0.5 \text { and } 2 \% \text { wt. }\end{array}$ & $\begin{array}{l}\text { Novel nanocomposite hydrogels were } \\
\text { produced; } \\
\text { Increased the degree of swelling and } \\
\text { the mechanical resistance. }\end{array}$ & $\begin{array}{l}\text { (da Costa et } \\
\text { al., 2016) }\end{array}$ \\
\hline $\mathrm{ADD}$ & $\begin{array}{l}\text { Synthetic } \\
\text { hectorite }\end{array}$ & $\begin{array}{l}\text { AAD: } 1-2 \mathrm{~g} \text {; } \\
\text { Synthetic hectorite: } 2 \mathrm{wt} \% \text {; } \\
\text { pH } 7 .\end{array}$ & $\begin{array}{l}\text { Electrostatic attractions; } \\
\text { Hydrogen bonding; } \\
\text { Rheological. }\end{array}$ & $\begin{array}{l}\text { (Huang et } \\
\text { al., 2019) }\end{array}$ \\
\hline
\end{tabular}

522 ADD: acrylamide, 2- acrylamido-2-methylpropane sulfonic acid, and diallyldimethylammonium chloride monomers 
HPAD: Hydrolyzed poly(acrylamide/dimethyl diallyl ammonium chloride)

PAM: Polyacrylamide

PECT/CS: pectin/chitosan

Generally, for cationic polyelectrolytes, they are adsorbed onto the smectite surface through hydrogen bonding interactions between the $\mathrm{Si}-\mathrm{OH}$ and $\mathrm{Al}-\mathrm{OH}$ groups and functional group of polyelectrolyte's (Nasser et al., 2013). Cationic polyelectrolytes can also interact with the smectite through ion exchange by the electrostatic attraction between the positively charged cationic polyelectrolytes and the negatively charged smectite. By contrast, electrostatic repulsion occurs between anionic polyelectrolytes and smectite surfaces because both carry the negative charge. The electrostatic repulsion weakens the adsorption of smectite by anionic polyelectrolytes, thereby reducing the adsorption capacity. It also interacts with the smectite through van der Waals and possibly by H-bonding. Amphoteric polyelectrolytes exhibit both cationic polyelectrolytes and anionic polyelectrolytes behavior and their adsorption capacities are in between the cationic and anionic polyelectrolytes. Under the same conditions, for the same polyelectrolyte with different surface charge types, the adsorption affinity of smectite surface are easier and stronger for polyelectrolytes in the order: cationic polyelectrolytes > amphoteric polyelectrolytes > anionic polyelectrolytes (Shaikh et al., 2017).

\section{Concluding remarks and future work}

Recent studies have significantly deepened the understanding of the interactions between smectites and polyelectrolytes. The polyelectrolytes contribute to the adsorption, flocculation and rheological behavior of aqueous smectite dispersion. It is expected that the use of such polyelectrolytes with smectites will enhances the smectite processing, separations and waste water treatment and oil well drilling fluid.

It is now known that different types of polyelectrolytes and type of smectite along with polyelectrolyte molecular weight, charge type and charge density affect the interactions between smectite and polyelectrolyte. Although great progress has been made but scientific knowledge of the role of interactions between smectite and polyelectrolyte is still in its infancy. Most of the current research on smectite and polyelectrolyte interactions has so far been concerned with montmorillonite and fewer studies exist on the interaction between polyelectrolytes and saponite or hectorite. In addition, the species of polyelectrolytes are numerous but only a few types have been investigated for their interactions with smectites. The accurate experimental evidence on the hydrogen bonding, hydrophobic interaction, ion binding, electrostatic interaction, and van der Waals forces are limited. In particular, no quantitative data and reliable equations have been established. Hence, the detailed models and mechanisms at the molecular or atomic level remain unclear.

Moreover, it needs to be mentioned that interactions between smectite and polyelectrolyte in wastewater treatment was mostly conducted at laboratory scale. Wastewater treatment by 
563 adsorption, flocculation and separation on an industrial scale is still a challenge. Desirable polyelectrolytes as flocculants and smectite should be economically able to provide enough removal efficiency for pollutants in wastewaters under a wide range of conditions. Meanwhile, the polyelectrolyte and the process should be environmentally friendly, cost-effective and easily reproducible.

The interaction between smectites and polyelectrolytes get conventionally involved in using smectite-polyelectrolyte system as adsorbent, flocculant, rheological additives. Some studies have demonstrated new applications in biomaterial, three-dimensional (3D) printable ink materials and sensor devices by taking advantage of the interaction of smectites with polyelectrolytes. The smectite-based nanocomposites and hierarchical materials can be fabricated by the surface engineering and tactic assembly of smectites. Interactions between smectites and polyelectrolytes can result in the formation of nanohybrids as biosensors, catalysts and drug carriers. In-depth understanding of the interaction between polyelectrolytes and smectites also helps expanding the integration and functionality and inherent mechanism of advanced smectite-polyelectrolyte materials. 


\section{References}

Aalaie, J., 2012. Rheological Behavior of Polyacrylamide/Laponite Nanoparticle Suspensions in Electrolyte Media J. Macromol. Sci. B. 51(6), 1139-1147.

Abdurrahmanoglu, S., Okay, O., 2010. Rheological behavior of polymer-clay nanocomposite hydrogels: Effect of nanoscale interactions. J. Appl. Polym. Sci. 116(4), 2328-2335.

Abu-Jdayil, B., 2011. Rheology of sodium and calcium bentonite-water dispersions: Effect of electrolytes and aging time. Int. J. Miner. Process. 98(3-4): 208-213.

Ahmad, H.M., Kamal, M.S., Al-Harthi, M.A., 2018. Rheological and filtration properties of clay-polymer systems: Impact of polymer structure. Appl. Clay. Sci. 160: 226-237.

Akhtarmanesh, S., Shahrabi, M.A., Atashnezhad, A., 2013. Improvement of wellbore stability in shale using nanoparticles. J. Petrol. Sci. Eng. 112: 290-295.

Alemdar, A., Bütün, V., 2005. Interaction between a tertiary amine methacrylate based polyelectrolyte and a sodium montmorillonite dispersion and its rheological and colloidal properties. J. Appl. Polym. Sci. 95(2): 300-306.

Alemdar, A., Öztekin, N., Erim, F., Ece, Ö., Güngör, N., 2005. Effects of polyethyleneimine adsorption on rheology of bentonite suspensions. B. Mater. Sci. 28(3): 287-291.

Aydin, M., Uyar, T., Tasdelen, M.A., Yagci, Y., 2015. Polymer/clay nanocomposites through multiple hydrogen-bonding interactions. J. Polym. Sci. A. Polym. Chem. 53(5): 650-658.

Bai, X., Yang, Y., Xiao, D., Pu, X., Wang, X., 2015. Synthesis, characterization, and performance evaluation of the AM/AMPS/DMDAAC/SSS quadripolymer as a fluid loss additive for water-based drilling fluid. J. Appl. Polym. Sci.132(14).

Bandla, M., Abbavaram, B.R., Kokkarachedu, V., Sadiku, R.E., 2017. Silver nanoparticles incorporated within intercalated clay/polymer nanocomposite hydrogels for antibacterial studies. Polym. Composite. 38: 16-23.

Barany, S., Meszaros, R., Kozakova, I., Skvarla, I., 2009. Kinetics and mechanism of flocculation of bentonite and kaolin suspensions with polyelectrolytes and the strength of floccs. Colloid. j. 71(3): 285-292.

Beisebekov, M.M., Serikpayeva, S.B., Zhumagalieva, S.N., Beisebekov, M.K., Abilov, Z.A., Kosmella, S., Koetz, J., 2014. Interactions of bentonite clay in composite gels of non-ionic polymers with cationic surfactants and heavy metal ions. Colloid. Polym. Sci. 293(2): 633-639.

Bergaya, F., Lagaly, G., 2013. General Introduction, Handbook of Clay Science. Dev. Clay. Sci. 1-19.

Blachier, C., Michot, L., Bihannic, I., Barres, O., Jacquet, A., Mosquet, M., 2009. Adsorption of polyamine on clay minerals. J. Colloid. Interface. Sci. 336(2): 599-606.

Budnyak, T.M., Yanovska, E.S., Kichkiruk, O.Y., Sternik, D., Tertykh, V.A., 2016. Natural Minerals Coated by Biopolymer Chitosan: Synthesis, Physicochemical, and Adsorption Properties. Nanoscale. Res. Lett. 11(492): 1-12.

Campos, V., Tcacenco, C.M., 2015. Synthesis of polycationic bentonite-ionene complexes and their benzene adsorption capacity. Polímeros. 25(2): 146-153.

Carli, L.N., Daitx, T.S., Guegan, R., Giovanela, M., Crespo, J.S., Mauler, R.S., 2015. Biopolymer nanocomposites based on poly(hydroxybutyrate-co-hydroxyvalerate) reinforced by a non-ionic organoclay. Polymer International. 64(2): 235-241. 
Chalah, K., Benmounah, A., Benyounes, K., 2018. Effect of anionic polyelectrolytes on the flow of activated sodium bentonite drilling mud. Matec. Web. Conf. Edp. Sci. 01082.

Chu, Q., Luo, P., Zhao, Q., Feng, J., Kuang, X., Wang, D., 2013. Application of a new family of organosilicon quadripolymer as a fluid loss additive for drilling fluid at high temperature. J. Appl. Polym. Sci.128(1): 28-40.

Craciun, G., Ighigeanu, D., Manaila, E., Stelescu, M.D., 2015. Synthesis and characterization of poly (acrylamide-co-acrylic acid) flocculant obtained by electron beam irradiation. Mater. Res. 18(5): 984-993.

da Costa, M.P., de Mello Ferreira, I.L., de Macedo Cruz, M.T., 2016. New polyelectrolyte complex from pectin/chitosan and montmorillonite clay. Carbohyd. Polym. 146: 123-30.

Dawson, J.I., Oreffo, R.O., 2013. Clay: new opportunities for tissue regeneration and biomaterial design. Advanced Materials. 25(30): 4069-86.

de Figueiredo, J.M.R., Araujo, J.P., Silva, I.A., Cartaxo, J.M., Neves, G.A., Ferreira, H.C., 2014. Purified Smectite Clays Organofilized with Ionic Surfactant for Use in Oil-based Drilling Fluids. In: S.M. Castanho, W. Acchar and D. Hotza (Editors), Brazilian Ceramic Conference 57. Materials Science Forum. 21-26.

de Souza, G.S., Luporini, S., Rigoli, I.C., 2017. Rheological characterization of saline clay dispersions with xanthan gum for oil well drilling fluids. Materia-Brazil. 22(1): 11796.

Del Gaudio, V., Luo, Y., Wang, Y., Wasowski, J., 2018. Using ambient noise to characterise seismic slope response: The case of Qiaozhuang peri-urban hillslopes (Sichuan, China). Eng. Geol. 246: 374-390.

Diouri, A., Chalah, K., Benmounah, A., Benyounes, K., Boukhari, A., Ait Brahim, L., Bahi, L., Khachani, N., Saadi, M., Aride, J., Nounah, A., 2018. Effect of anionic polyelectrolytes on the flow of activated sodium bentonite drilling mud. Matec. Web. Conf. 149.

Du, Z.S., Hu, Y., Gu, X.Y., Hu, M., Wang, C.Y., 2016. Poly(acrylamide) microgel-reinforced poly(acrylamide)/hectorite nanocomposite hydrogels. Colloid. Surface. A. 489: 1-8.

Ehsan, A., Jamal, A., Mahmood, H., Ahmad, S.V., 2017. Thermal stability, adsorption and rheological behaviors of sulfonated polyacrylamide/chromium triacetate/laponite nanocomposite weak gels. Macromol. Res. 25(1): 27-37.

Ewanek, J., 2008. Water-Based Polymer Drilling Fluid and Method of Use. US.

Falode, O., Ehinola, O., Nebeife, P., 2008. Evaluation of local bentonitic clay as oil well drilling fluids in Nigeria. Appl. Clay. Sci. 39(1-2): 19-27.

Gong, Y., Tian, R., Li, H., 2018. Coupling effects of surface charges, adsorbed counterions and particle-size distribution on soil water infiltration and transport. Eur. J. Soil. Sci. 69(6): 1008-1017.

Gumfekar, S.P., Soares, J.B.P., 2018. A novel hydrophobically-modified polyelectrolyte for enhanced dewatering of clay suspension. Chemosphere. 194: 422-431.

Hasan, A., Fatehi, P., 2018. Cationic kraft lignin-acrylamide as a flocculant for clay suspensions: 1. Molecular weight effect. Sep. Purif. Technol. 207: 213-221.

Hasan, A., Fatehi, P., 2019. Cationic kraft lignin-acrylamide copolymer as a flocculant for clay suspensions: (2) Charge density effect. Sep. Purif. Technol. 210: 963-972.

Heller, H., Keren, R., 2002. Anionic Polyacrylamide Polymers Effect on Rheological Behavior of Sodium-Montmorillonite Suspensions. Soil. Sci. Soc. Am. J. 66(1): 19-25. 
Huang, X., Lv, K., Sun, J., Lu, Z., Bai, Y., Shen, H., Wang, J., 2019. Enhancement of thermal stability of drilling fluid using laponite nanoparticles under extreme temperature conditions. Mater. Lett. 248: 146-149.

Ismadji, S., Soetaredjo, F.E., Ayucitra, A., 2015. Natural Clay Minerals as Environmental Cleaning Agents, Clay Materials for Environmental Remediation. SpringerBriefs in Molecular Science. 5-37.

Kafashi, S., Rasaei, M., Karimi, G., 2017. Effects of sugarcane and polyanionic cellulose on rheological properties of drilling mud: an experimental approach. Egy. J. Petro. 126(2): 371-374.

Karagüzel, C., Çetinel, T., Boylu, F., Çinku, K., Çelik, M., 2010. Activation of (Na, Ca)-bentonites with soda and $\mathrm{MgO}$ and their utilization as drilling mud. Appl. Clay. Sci. 48(3): 398-404.

Karimi, F., Qazvini, N.T., Namivandi-Zangeneh, R., 2013. Fish gelatin/laponite biohybrid elastic coacervates: A complexation kinetics-structure relationship study. Int. J. Bbiol. Macromol. 61: 102-113.

Kelessidis, V.C., Zografou, M., Chatzistamou, V., 2013. Optimization of drilling fluid rheological and fluid loss properties utilizing PHPA polymer. Soc. Petrole. Eng.

Khoshniyat, A., Hashemi, A., Sharif, A., Aalaie, J., Duobis, C., 2012. Effect of surface modification of bentonite nanoclay with polymers on its stability in an electrolyte solution. Polym. Sci. Ser. B. 54(1-2): 61-72.

Kim, U., Carty, W.M., 2016. Effect of polymer molecular weight on adsorption and suspension rheology. J. Ceram. Soc. Jap. 124(4): 484-488.

Kudaibergenov, S.E., Ciferri, A., 2007. Natural and Synthetic Polyampholytes, 2: Functions and Applications. Macromol. Rapid. Comm. 28(20): 1969-1986.

Lee, C.S., Robinson, J., Chong, M.F., 2014. A review on application of flocculants in wastewater treatment. Process. Saf. Environ. 92(6): 489-508.

Li, C., Wu, Q., Petit, S., Gates, W.P., Yang, H., Yu, W., Zhou, C., 2019a. Insights into the Rheological Behavior of Aqueous Dispersions of Synthetic Saponite: Effects of Saponite Composition and Sodium Polyacrylate. Langmuir. 35(40): 13040-13052.

Li, M., Wu, Q., Song, K., Qing, Y. and Wu, Y., 2015. Cellulose nanoparticles as modifiers for rheology and fluid loss in bentonite water-based fluids. Appl. Mater. Interface. 7: 5006-5016.

Li, P., Kim, N.H., Heo, S.-B., Lee, J.-H., 2008. Novel PAAm/Laponite clay nanocomposite hydrogels with improved cationic dye adsorption behavior. Compos. Part. B-Eng. 39(5): 756-763.

Lin, L., Luo, P., 2018. Effect of polyampholyte-bentonite interactions on the properties of saltwater mud. Appl. Clay. Sci. 163: 10-19.

Liu, F., Jiang, G., Peng, S., He, Y., Wang, J., 2016. Amphoteric polymer as an anti-calcium contamination fluid-loss additive in water-based drilling fluids. Energ. Fuel. 30(9): 7221-7228.

Mansri, A., Hocine, T., Bouras, B., Ben-habib, K., 2019. Synthesis of a new flocculant based on poly(acrylamide-co-(N-octyl-4-vinylpyridinium bromide)) [AM5/VP5C8Br]-application for the turbidity removal from clay suspension. J. Macromol. Sci. A. 56(1): 96-103. 
Marchuk, S., Churchman, J., Rengasamy, P., 2016. Possible effects of irrigation with wastewater on the clay mineralogy of some Australian clayey soils: laboratory study. Soil. Res.54(7): 857-868.

Mishchenko, M., Ozheredov, I., Postnova, I., Sapozhnikov, D., Shkurinov, A., Shchipunov, Y.A., 2016. A terahertz spectroscopic study of chitosan-based bionanocomposites containing clay nanoparticles. Colloid J. 78(2): 189-195.

Mpofu, P., Addai-Mensah, J., Ralston, J., 2004. Flocculation and dewatering behaviour of smectite dispersions: effect of polymer structure type. Miner. Eng. 17(3): 411-423.

N. Güngör, S.K.1., 2001. Interactions of polyacrylamide polymer with bentonite in aqueous systems. Mater. Lett. 48: 168-175.

Nakamura, T., Ogawa, M., 2013. Adsorption of cationic dyes within spherical particles of poly(N-isopropylacrylamide) hydrogel containing smectite. Appl. Clay. Sci. 83-84: 469-473.

Nazarzadeh, M., Nikfarjam, N., Qazvini, N.T., 2017. Flocculation properties of a natural polyampholyte: The optimum condition toward clay suspensions. Environ. Eng. Res. 22(3): 255-265.

Nasser, M., Twaiq, F., Onaizi, S.A., 2013. Effect of polyelectrolytes on the degree of flocculation of papermaking suspensions.Sep. Purif. Technol. 103: 43-52.

Oliyaei, N., Aalaie, J., Barati, A., Miri, T., 2015. Study on Steady Shear Rheological Behavior of Concentrated Suspensions of Sulfonated Polyacrylamide/Na-Montmorillonite Nanoparticles. J. Macromol. Sci. B. 54(7): 761-770.

Oztekin, N., 2017. Removal of sodium dodecylbenzenesulfonate from aqueous solution using polyethyleneimine-modified bentonite clay. Desalin. Water. Treat. 80: 268-275.

Petzold, G., Schwarz, S., 2013. Polyelectrolyte complexes in flocculation applications. Adv. Polym. Sci. 256: 25-65.

Postnova, I., Sarin, S., Silant'ev, V., Ha, C.-S., Shchipunov, Y., 2015. Chitosan bionanocomposites prepared in the self-organized regime. Pure. Appl. Chem. 87(8): 793-803.

Rabiee, A., Ershad-Langroudi, A., Jamshidi, H., 2014. Polyacrylamide-based polyampholytes and their applications. Rev. Chem. Eng.30(5): 501-519.

Sakhawoth, Y., Michot, L.J., Levitz, P., Malikova, N., 2017. Flocculation of Clay Colloids Induced by Model Polyelectrolytes: Effects of Relative Charge Density and Size. Chemphyschem. 18(19): 2756-2765.

Santhosh, C., Velmurugan, V., Jacob, G., Jeong, S.K., Grace, A.N., Bhatnagar, A., 2016. Role of nanomaterials in water treatment applications: A review. Chem. Eng. J. 306: 1116-1137.

Sas, S., Danko, M., Bizovská, V., Lang, K., Bujdák, J., 2017. Highly luminescent hybrid materials based on smectites with polyethylene glycol modified with rhodamine fluorophore. Appl. Clay. Sci. 138: 25-33.

Shaikh, S.M.R., Nasser, M.S., Hussein, I., Benamor, A., Onaizi, S.A., Qiblawey, H., 2017 a. Influence of polyelectrolytes and other polymer complexes on the flocculation and rheological behaviors of clay minerals: A comprehensive review. Sep. Purif. Technol. 187: 137-161.

Shaikh, S.M.R., Nasser, M.S., Hussein, I.A., Benamor, A., 2017b. Investigation of the effect of polyelectrolyte structure and type on the electrokinetics and flocculation behavior of bentonite dispersions. Chem. Eng. J. 311: 265-276. 
Shchipunov, Y., Ivanova, N., Silant'ev, V., 2009. Bionanocomposites formed by in situ charged chitosan with clay. Green Chem. 11(11): 1758.

Shchipunov, Y.A., Sarin, S.A., Silant'ev, V.E., Postnova, I.V., 2012a. Self-organization in the chitosan-clay nanoparticles system regulated through polysaccharide macromolecule charging. 2. Films. Colloid. J. 74(5): 636-644.

Shchipunov, Y.A., Silant'ev, V., Postnova, I., 2012b. Self-organization in the chitosan-clay nanoparticles system regulated through polysaccharide macromolecule charging. 1. Hydrogels. Colloid. J. 74(5): 627-635.

Sievers, D.A., Lischeske, J.J., Biddy, M.J., Stickel, J.J., 2015. A low-cost solid-liquid separation process for enzymatically hydrolyzed corn stover slurries. Bioresource. Technol. 187: $37-42$.

Silva, J.M., Reis, R.L., Mano, J.F., 2016. Biomimetic Extracellular Environment Based on Natural Origin Polyelectrolyte Multilayers. Small, 12(32): 4308-4342.

Song, J., Yamagushi, T., Silva, D.J., Hubbe, M.A., Rojas, O.J., 2010. Effect of Charge Asymmetry on Adsorption and Phase Separation of Polyampholytes on Silica and Cellulose Surfaces. Journal of Physical Chemistry B. 114(2): 719-727.

Sposito, G., Skipper, N.T., Sutton, R., Park, S.-h., Soper, A.K., Greathouse, J.A., 1999. Surface geochemistry of the clay minerals. Proceedings of the National Academy of Sciences. 96(7): 3358-3364.

Stöter, M., Rosenfeldt, S., Breu, J., 2015. Tunable Exfoliation of Synthetic Clays. Annu. Rev. Mater. Res. 45(1): 129-151.

Takeno, H., Kimura, Y., 2016. Molecularweight effects on tensile properties of blend hydrogels composed of clay and polymers. Polym. 85: 47-54.

Takeno, H., Nakamura, A., 2019. Effects of molecular mass of polymer on mechanical properties of clay/poly (ethylene oxide) blend hydrogels, and comparison between them and clay/sodium polyacrylate blend hydrogels. Colloid. Polym. Sci. 297(4): 641-649.

Takeno, H., Nakamura, W., 2013. Structural and mechanical properties of composite hydrogels composed of clay and a polyelectrolyte prepared by mixing. Colloid. Polym. Sci. 291(6): 1393-1399.

Tarasova, E., Naumenko, E., Rozhina, E., Akhatova, F., Fakhrullin, R., 2019. Cytocompatibility and uptake of polycations-modified halloysite clay nanotubes. Appl. Clay. Sci. 169: 21-30.

Tong, Z., Deng, Y., 2013. The formation of asymmetric polystyrene/saponite composite nanoparticles via miniemulsion polymerization. J. Appl. Polym. Sci. 127(5): 3916-3922.

Van Haver, L., Nayar, S., 2017. Polyelectrolyte flocculants in harvesting microalgal biomass for food and feed applications. Algal. Res. 24: 167-180.

Vereb, G., Nagy, L., Kertesz, S., Kovacs, I., Hodur, C., Laszlo, Z., 2017. Highly Efficient Purification of Finely Dispersed Oil Contaminated Waters By Coagulation/Flocculation Method and Effects on Membrane Filtration. Stud. U. Babes-Bol. Che. 62(2): 259-270.

Vipulanandan, C., Mohammed, A.S., 2014. Hyperbolic rheological model with shear stress limit for acrylamide polymer modified bentonite drilling muds. J. Petrol. Sci. Eng. 122: 38-47.

Viseras, C., Cerezo, P., Sanchez, R., Salcedo, I., Aguzzi, C., 2010. Current challenges in clay minerals for drug delivery. Appl. Clay. Sci. 48(3): 291-295. 
Wang, S., Konduri, M.K.R., Hou, Q., Fatehi, P., 2016. Cationic xylan-METAC copolymer as a flocculant for clay suspensions. RSC Adv. 6(46): 40258-40269.

Wang, X., Yang, L., Zhang, J., Wang, C., Li, Q., 2014. Preparation and characterization of chitosan-poly (vinyl alcohol)/bentonite nanocomposites for adsorption of $\mathrm{Hg}$ (II) ions. Chem. Eng. J. 251: 404-412.

Wang, Z., Huang, W.X., Yang, G.H., Liu, Y., Liu, S., 2019. Preparation of cellulose-base amphoteric flocculant and its application in the treatment of wastewater. Carbohyd. Polyme, 215: 179-188.

Xiao, S., Castro, R., Maciel, D., Goncalves, M., Shi, X., Rodrigues, J., Tomas, H., 2016. Fine tuning of the $\mathrm{pH}$-sensitivity of laponite-doxorubicin nanohybrids by polyelectrolyte multilayer coating. Mater Sci Eng C Mater Biol Appl, 60: 348-356.

Yu, L., Zhang, J., Li, G., Zhao, H., Liu, T., 2018. Research and Application of Plugging Drilling Fluid with Low-Activity and High Inhibition Properties. Petroleum Drilling Techniques, 46(1): 44-48.

Zhang, B., Su, H., Gu, X., Huang, X., Wang, H., 2013a. Effect of structure and charge of polysaccharide flocculants on their flocculation performance for bentonite suspensions. Colloid. Surface. A. 436: 443-449.

Zhang, J., Chen, M., Tian, J., Li, W., Xiao, J., 2005. Effect of Mixed Anionic-Cationic Polyacrylamide on Rheological Properties of Smectite Gel. Acta Petrolei Sinica Petroleum Processing Section. 21(3): 84.

Zhang, J., Wang, Q. Jiang, J., 2013b. Lime mud from paper-making process addition to food waste synergistically enhances hydrogen fermentation performance. Int. J. Hydrogen. Energy. 38(6): 2738-2745.

Zhao, Y., Cavallaro, G., Lvov, Y., 2015. Orientation of charged clay nanotubes in evaporating droplet meniscus. J Colloid Interface Sci, 440: 68-77.

Zhen, R., Chi, Q., Wang, X., Yang, K., Jiang, Y., Li, F., Xue, B., 2016. Crystallinity, ion conductivity, and thermal and mechanical properties of poly (ethylene oxide)-illite nanocomposites with exfoliated illite as a filler. J. Appl. Polym. Sci.133(47).

Zhou, C.H., Cun Jun, L., Gates, W.P., Zhu, T.T. and Wei Hua, Y., 2019a. Co-intercalation of organic cations/amide molecules into montmorillonite with tunable hydrophobicity and swellability. Appl. Cla.y Sci.179:1-11.

Zhou, C.H., Zhou, Q., Wu, Q.Q., Petit, S., Jiang, X.C., Xia, S.T., Li, C.S., Yu, W.H., 2019 b. Modification, hybridization and applications of saponite: An overview. Appl. Clay. Sci. 168: 136-154.

Zhou, D.J., Zhang, Z.P., Tang, J.L., Wang, F.W., Liao, L.B., 2016. Applied properties of oil-based drilling fluids with montmorillonites modified by cationic and anionic surfactants. Appl. Clay Sci. 121: 1-8.

Zhu, T.T., Zhou, C.H., Kabwe, F.B., Wu, Q.Q., Li, C.S., Zhang, J.R., 2019. Exfoliation of montmorillonite and related properties of clay/polymer nanocomposites. Appl. Clay. Sci. 169: 48-66. 